\title{
Title: Function-based Biosensor for Hazardous Waste Toxin Detection
}

\section{Type of Report: Final Scientific/Technical Report}

Start Date: $04 / 01 / 2002$

End Date: 03/31/2007

Principle Author(s): James J. Hickman, University of Central Florida

Date Report was issued: July, 2008

Clemson University: Previous DOE Award /number: DE-FG-02-00ER45856

University of Central Florida: DOE Award /number: DE-FG-02-04ER46171

Name and Address of submitting organization (also any significant subcontractors/sub recipients participating in the report)

Office of Research and Commercialization

University of Central Florida

12201 Research Parkway, Suite 501

Orlando, FL 32826 


\section{DISCLAIMER* --}

“This report was prepared as an account of work sponsored by an agency of the United States Government. Neither the United States Government nor any agency thereof, nor any of their employees, makes any warranty, express or implied, or assumes any legal liability or responsibility for the accuracy, completeness, or usefulness of any information, apparatus, product, or process disclosed, or represents that its use would not infringe privately owned rights. Reference herein to any specific commercial product, process, or service by trade name, trademark, manufacturer, or otherwise does not necessarily constitute or imply its endorsement, recommendation, or favoring by the United States Government or any agency thereof. The views and opinions of authors expressed herein do not necessarily state or reflect those of the United States Government or any agency thereof.” 


\begin{abstract}
There is a need for new types of toxicity sensors in the DOE and other agencies that are based on biological function as the toxins encountered during decontamination or waste remediation may be previously unknown or their effects subtle. Many times the contents of the environmental waste, especially the minor components, have not been fully identified and characterized. New sensors of this type could target unknown toxins that cause death as well as intermediate levels of toxicity that impair function or cause long term impairment that may eventually lead to death. The primary question posed in this grant was to create an electronically coupled neuronal cellular circuit to be used as sensor elements for a hybrid non-biological/biological toxin sensor system. A sensor based on the electrical signals transmitted between two mammalian neurons would allow the marriage of advances in solid state electronics with a functioning biological system to develop a new type of biosensor. Sensors of this type would be a unique addition to the field of sensor technology but would also be complementary to existing sensor technology that depends on knowledge of what is to be detected beforehand. We integrated physics, electronics, surface chemistry, biotechnology, and fundamental neuroscience in the development of this biosensor. Methods were developed to create artificial surfaces that enabled the patterning of discrete cells, and networks of cells, in culture; the networks were then aligned with transducers. The transducers were designed to measure electromagnetic fields (EMF) at low field strength. We have achieved all of the primary goals of the project. We can now pattern neurons routinely in our labs as well as align them with transducers. We have also shown the signals between neurons can be modulated by different biochemicals. In addition, we have made another significant advance where we have repeated the patterning results with adult hippocampal cells. Finally, we demonstrated that patterned cardiac cells on microelectrode arrays could act as sensors as well.
\end{abstract}




\section{TABLE OF CONTENTS}

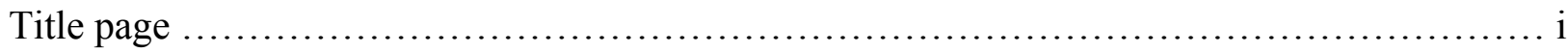

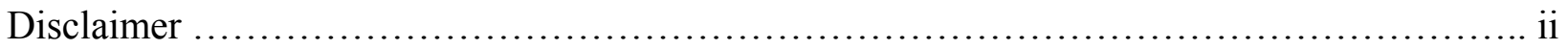

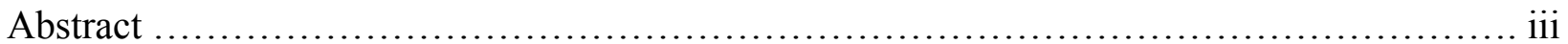

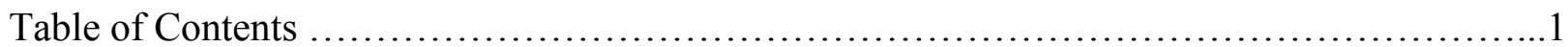

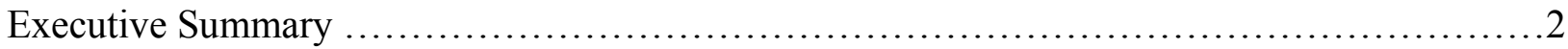

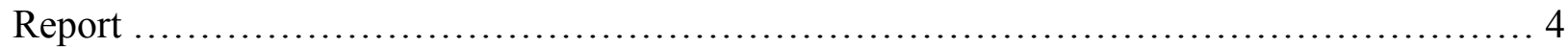

Experimental methods ......................................................4

Results and Discussion ......................................................... 4

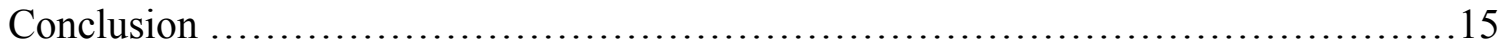

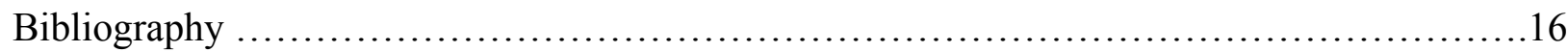

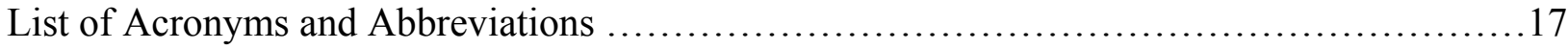

Refereed Conference Proceedings .................................................... 17

Published Abstracts ............................................................. 19

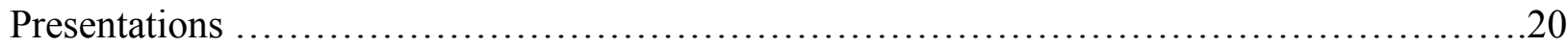

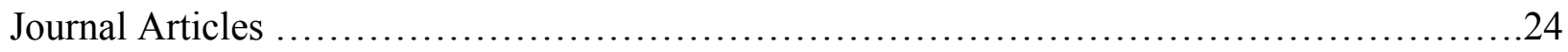

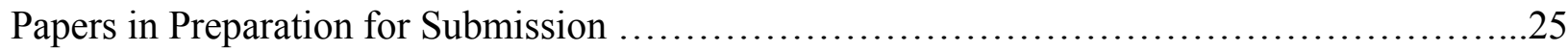

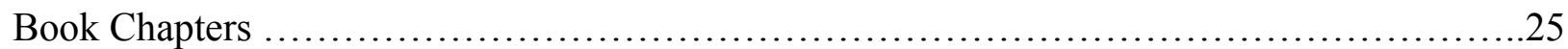




\section{EXECUTIVE SUMMARY}

There is a need for new types of toxicity sensors in the DOE and other agencies that are based on biological function as the toxins encountered during decontamination or waste remediation may be previously unknown or their effects subtle. Many times the contents of the environmental waste, especially the minor components, have not been fully identified and characterized. New sensors of this type could target unknown toxins that cause death as well as intermediate levels of toxicity that impair function or cause long term impairment that may eventually lead to death. Information of this kind is currently obtained primarily from epidemiological studies on animals or humans. It would be beneficial to develop sensors to function as precursors to these types of studies or eliminate their need entirely. Thus, programs that monitor hazardous waste bioremediation and waste disposal would benefit from these new sensors based on cell-cell communication. One of the reasons they have not been developed to date is the wide range of expertise needed for their reduction to practice. However, if developed, these types of sensors would add to the ability of the DOE to ensure the safety of the communities surrounding bioremediation sites or civilian threats of CBW. The idea of this grant is to integrate microsystems fabrication technology and cellular components with the aim of initiating self-assembly and growth into a biologically, mechanically and electrically interactive multicomponent system. Aspects of this system have been previously investigated including the use of microstructures to control the biology and the use of surface chemistry to pattern cells. However, this is one of the first attempts to combine all of the required parts to create a useful system for understanding neuronal circuits and for beginning to create multicellular systems using cells as components. A sensor based on the electrical signals transmitted between two mammalian neurons would allow the marriage of advances in solid state electronics with a functioning biological system to develop a new type of biosensor. The development of a solid state device to monitor neuronal signals combined with surface patterning would enable a sensor based on rudimentary cognitive function. This sensor concept is unique in that it can act not only as a screen for known compounds but unknowns as well. These function-based sensors could detect toxins or environmental effects ranging from the obvious (cell death) to those that are more subtle (impairment of function). Using such a device we could measure this wide range of responses because neurons and the networks they form are exceedingly sensitive to certain changes in their environment.

This has been a highly successful research program in that, over the time course of the funding for this research, we can now routinely create well-defined patterns of hippocampal neurons in vitro. It is important that we can recreate these well-defined culture circuits from hippocampal neurons as the hippocampus is the portion of the brain that most think is responsible for learning and memory and many other cognitive functions. It is also one of the more susceptible regions of the body for toxins and disease, as damage to these neurons and their circuits have profound impact on animal or human function. We have also been able to model these simple circuits as well as align them with microelectrode arrays (MEA) that together enable the rudimentary sensor systems that were envisioned when the initial grant was funded. Advances in the basic biology of the embryonic hippocampal neurons have enabled us to create mixed populations of excitatory and inhibitory phenotypes on the patterns. This crucial result is one of the most fundamental processes we would like to mimic in vitro, that is important in vivo, is long-term potentiation (LTP) and long-term depression (LTD). LTP has now successfully been demonstrated utilizing patterns of hippocampal neurons on MEAs. This result, along with the techniques that make fabrication of these devices routine, were the primary goals of this project 
and they have now been achieved. Thus, the capability that was originally anticipated form this work, which are sensor systems, utilizing living neurons that could act as sensors for toxins or other environmental effects and how this affects cognitive functions has been achieved. In addition, detection of these affects can be made without cell death.

While we have achieved the main objective of this research, these are not the only significant results that have been achieved. We have also demonstrated for the first time that these culture systems could also be created from adult hippocampal neurons and that these systems could survive for at least 2-3 months and they are minimal to the same patterning methodologies as the embryonic cells. The importance of utilizing adult cells is that, even though our group and many others has shown that embryonic hippocampal cells can be made to exhibit many of the same functions as found in mature hippocampal cells, there is always the question as to whether or not they exhibit the full range of properties one would find in an adult cell in vivo. By now being able to routinely culture the adult cells, you can use these directly either in the sensor systems themselves or in control systems to verify that the mature embryonic cultures possess the same properties as the fully developed adult cells because the adult cells can be manipulated using the same surface chemistry techniques as the embryonic cells. It should be minimal to integration with MEA systems.

Finally, as a conclusion to some work that was initiated in an earlier granting period where we used cardiac cells as we did not have the facilities to do primary neuronal culture at that time, we have also established robust cell-based systems based on cardiac MEA constructs. These systems have been shown to be excellent toxin sensors and show great promise for a wide variety of applications in sensors.

These biological/non-biological hybrid device would be a major demonstration of the ability to combine surface chemistry and microsystems to create systems and to provide a novel, biologically founded solution to the next generation of sensor problems. We believe that the demonstration of this concept and its availability as a new model system will further the aims of the DOE and that the idea of bioengineering cells to build natural but also unnatural constructs also has major implications for future DOE projects. 


\section{REPORT DETAILS}

Experimental Methods: This grant was to create functional, simple, reproducible circuits that respond to a series of known compounds in a characteristic manner. The technical approach was divided into three tasks. Task 1 involved the culturing of rat hippocampal neurons on control unpatterned substrates, the patterning of those substrates, and the development of the culture conditions to increase the longevity of the neurons as well as tailoring the resultant neuronal phenotypes. This task was also to determine the factors that can control the number, placement, and fixing of synapses as this is a crucial factor in reproducible device fabrication necessary for Task 3. Task 2 was devoted to the characterization of systems developed in Task 1. The characterization methods included dual patch-clamp electrophysiology, neuronal morphology and surface analyses both before and after cell culture. Task 3 involved the construction and the characterization of the rudimentary biosensor devices. This task was also to design and fabricate the solid-state systems for the integrated device. The detailed methods for all of the procedures can be found in the manuscripts already published from this work that are listed in the report.

\section{Results and Discussions:}

Pattern Optimization: We have created a combination pattern $(100,200,300,400,500 \mu \mathrm{m}$ size, 1, 2, 3, $4 \mu \mathrm{m}$ line width) to test the influence of the size and the line-width of the patterns on the correctness of the cellular pattern formation (Figure 1). The total number of cells on the patterns was strongly dependent on the size of the pattern, and less on the line width. The number of correct cells (sitting on the cell attachment sites) practically was not affected by any of the measured parameters (feature size or line width). The ratio of the correct patterns measured by the 'Pattern Correctness Index' (calculated as correct cells*correct cells/total cells) declined with increasing feature size, but it was only slightly dependent on the line width (Figure 2). We concluded that the optimal pattern has a $200 \mu \mathrm{m}$ size and $2 \mu \mathrm{m}$ line width. Moreover, this feature size is compatible with commercial multielectrode arrays ( $200 \mu \mathrm{m}$ electrode spacing).

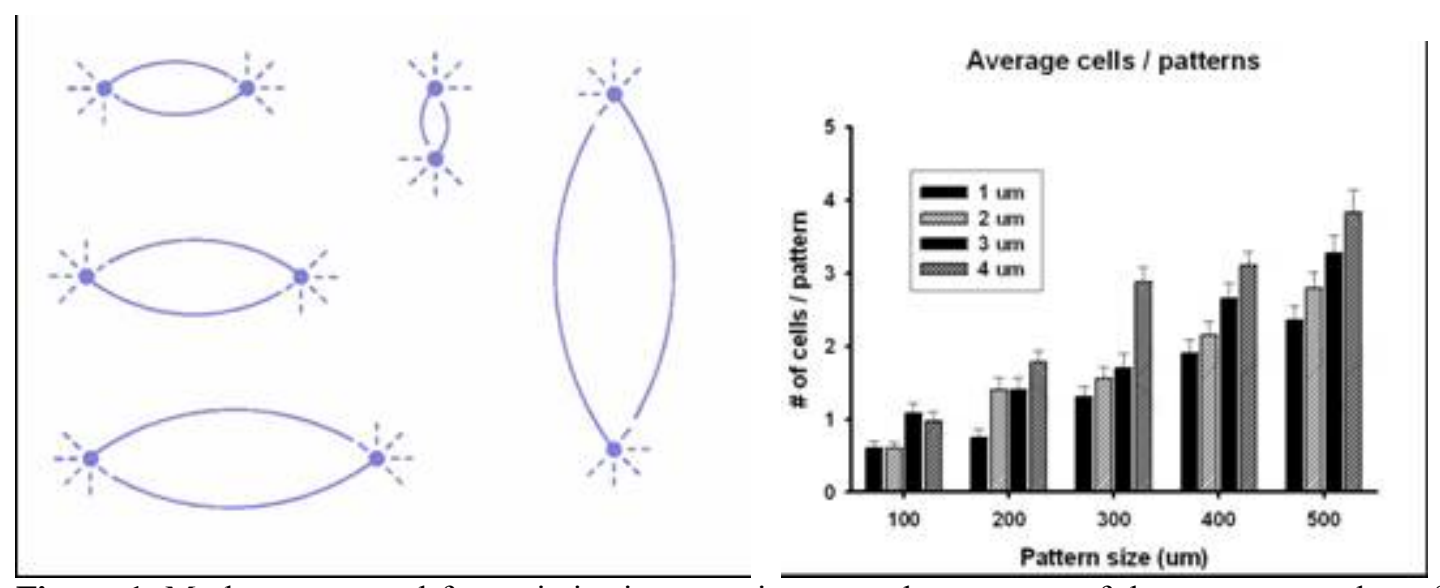

Figure 1. Mask pattern used for optimization experiments and a measure of the average number of cells on each pattern. 

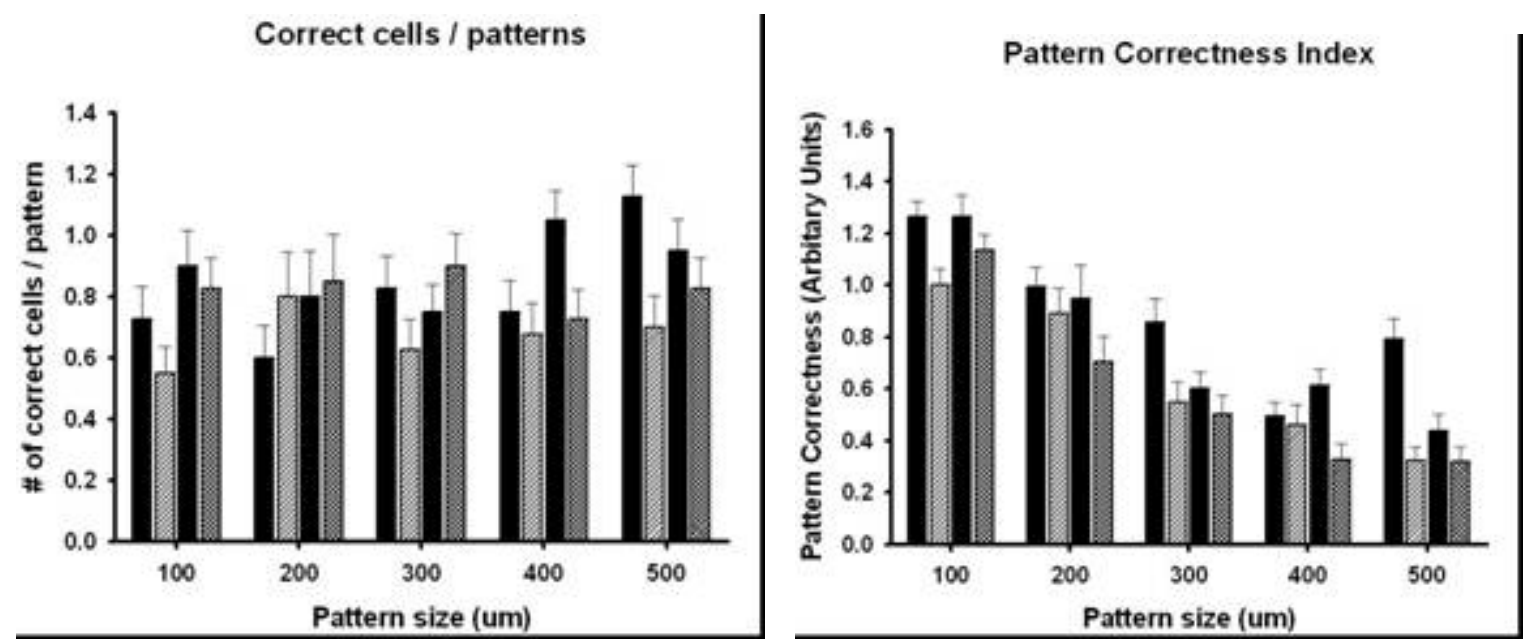

Figure 2. Characterization of the effect of feature size and line width on cellular pattern formation.

These statistical data were in good agreement with observations we obtained using our timelapse imaging system (Figure 3).
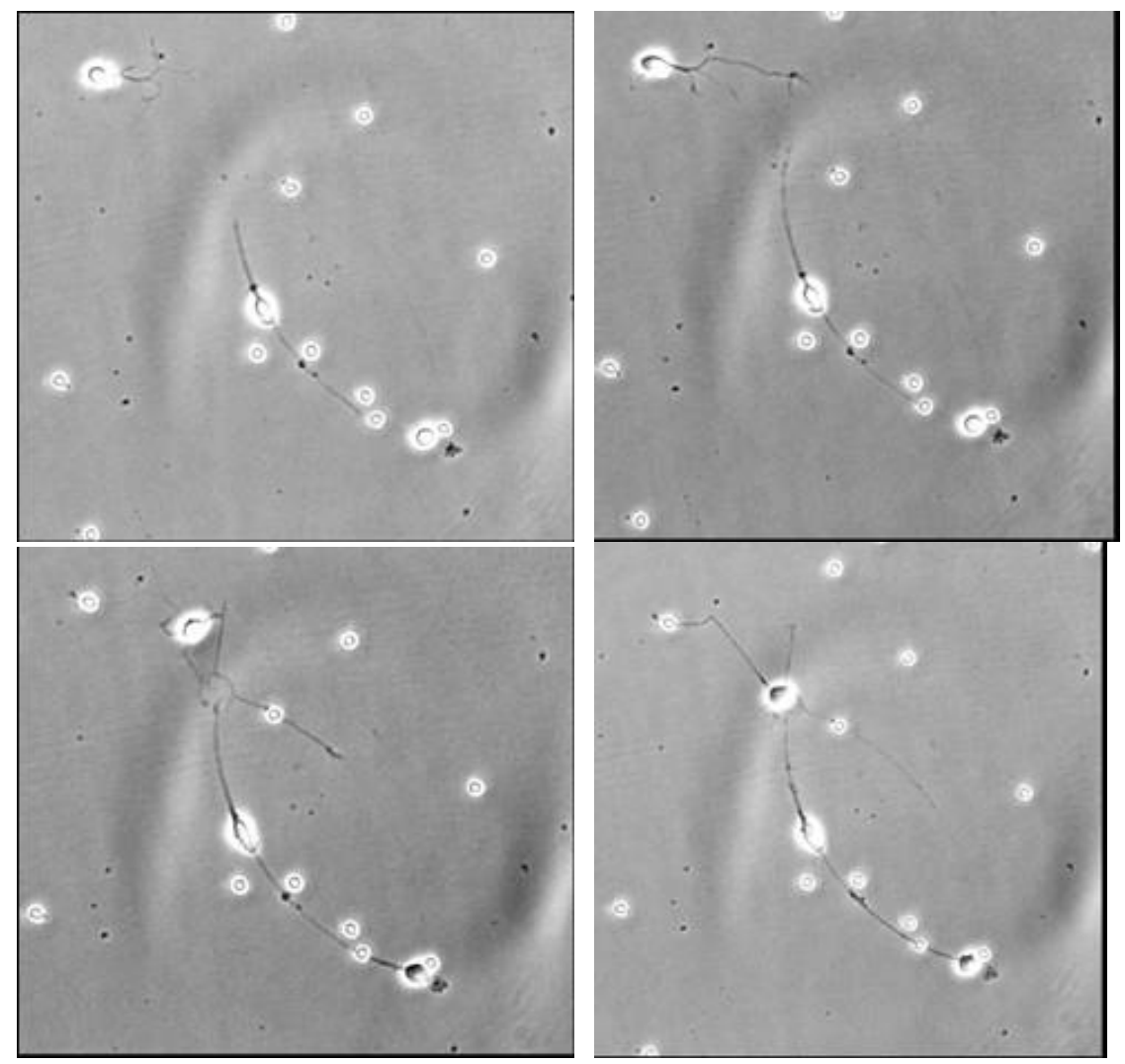

Figure 3. Time-lapse images of pattern formation. First, the neurons 'explore' their environment through their processes, when favorable attachment area was found, the cell body moved to that area.

Time-lapse measurements combined with rational pattern design also made possible the systematic study of the factors involved in cell migration. The initial results also indicated specific distances the cells can migrate over a hydrophobic surface, in effect establishing a threshold over which migration to a pattern can not occur. Geometry, soluble factors, surface 
signaling molecules and cell types (stem cells for example) can be varied in our in vitro system in future studies.

\section{Formation of Circuits for LTP and LTD}

We have successfully demonstrated for the first time hippocampal circuit patterns composed of a combination of excitatory and inhibitory neurons, which is a major advance. As indicated in our previous work, the modeling results for the various types of circuits were predicated on accomplishing this key goal. Engineered localized networks of embryonic hippocampal cells were created with photolithography and surface chemistry using selfassembled monolayers and optimized as indicated in the previous section. The physiology of the individual components and network dynamics was studied using dual patch-clamp electrophysiological recordings. Figure 4 indicates a phase contrast micrograph of a hippocampal cell circuit that has two electrical connections to the network through patch-clamp micropipets as well as electrophysiological characterization of the individual neurons.
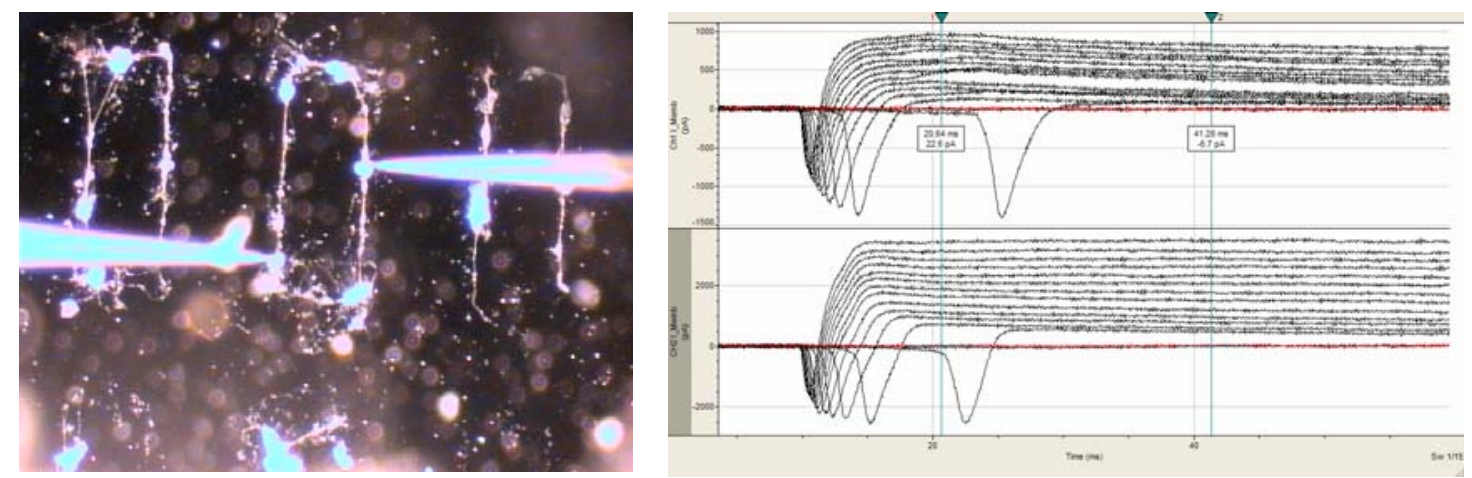

Figure 4. Electrophysiological characterization of engineered neuronal networks. Left panel: Representative brightfield picture $(4 \mathrm{x})$ of dual patch-clamp recordings from hippocampal cells cultured on a circuit pattern. Right panel: voltage-clamp recordings from the individual cells. Voltage-dependent sodium and potassium currents were evoked by $200 \mathrm{~ms}$ voltage steps from a holding of $-70 \mathrm{mV}$.

Figure 5 illustrates the electrophysiological recordings from the patterns that are indicative of excitatory and inhibitory cells in the same network. 

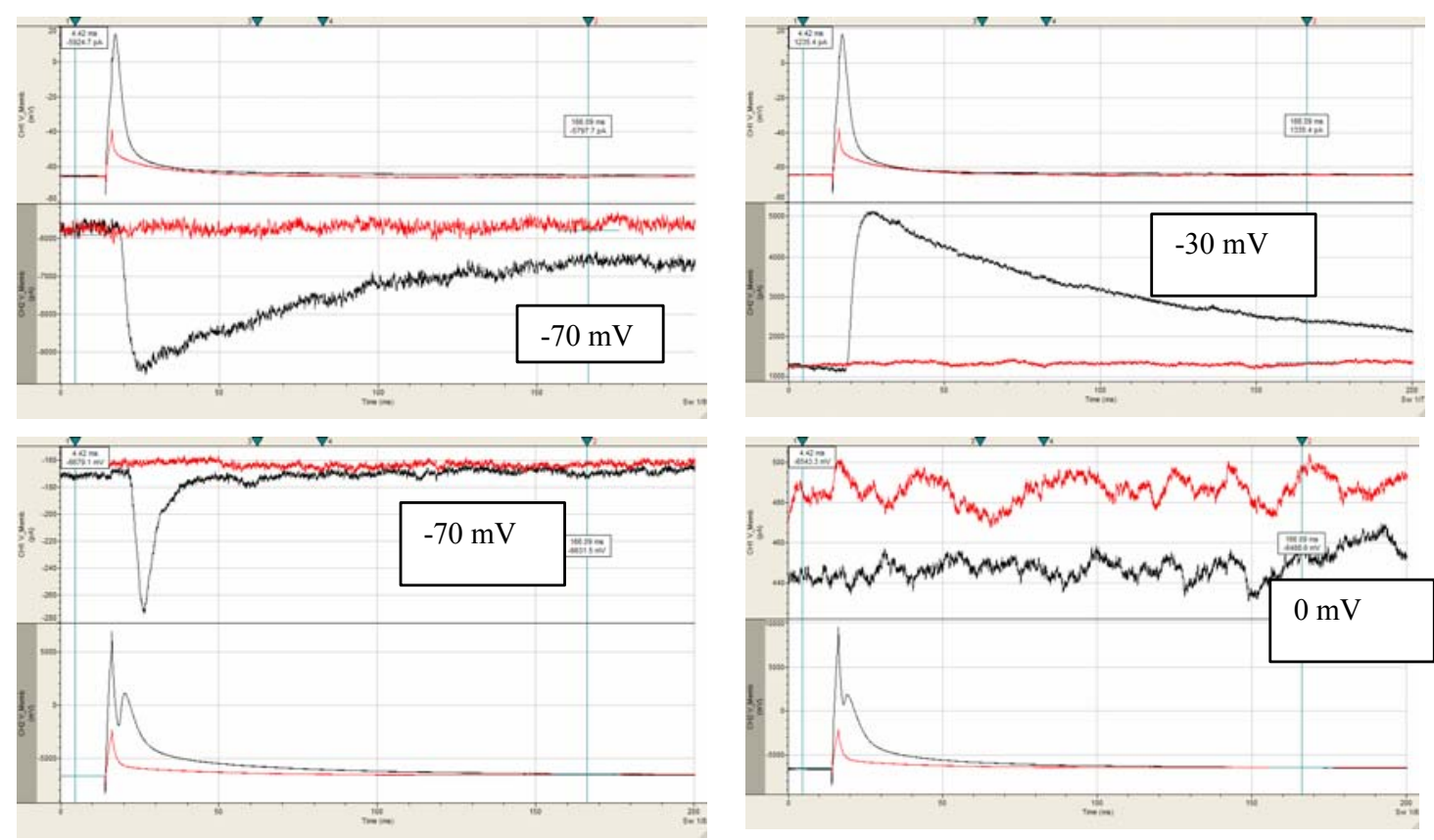

Figure 5. Dual-patch clamp recordings from engineered neuronal networks. Upper panel: Action potentials were evoked in cell 1 with depolarizing current injections in current-clamp mode, whereas synaptic currents were recorded in cell 2 in voltage-clamp mode. Lower panel: cell 2 was stimulated and synaptic currents in cell 1 were recorded. Left and right panels show the synaptic currents at different membrane potentials indicating that the reversal potential for the current in cell 1 is between -30 and $-70 \mathrm{mV}$ (etc. it is a chloride current mediated by GABAA receptors which indicates an inhibitory neuron) whereas for cell 2 it is around $0 \mathrm{mV}$ (it is mediated by AMPA receptors which indicates an excitatory neuron).

We also investigated the effects of transitioning the networks to 3 dimensional (3D) structures and compared the initial results to 2D neuronal networks, as 3D cultures of neurons are much closer to simulate the 3D structures characteristic to in vivo physiological systems than the standard 2D cultures. We developed the conditions to create engineered 3D neuronal networks using collagen hydrogels. Figure 6 indicated confocal microscopy images of 2D and 3D hippocampal neurons and Figure 7 shows electrophysiological recording for single cells (left) and from synapse formation (right) and the electrical characteristics are shown in table 1 . This is a real tour-de-force for one of the $\mathrm{Ph}$.D. students (Tao $\mathrm{Xu}$ ) to be able to perform patch-clamp electrophysiology in soft media. This work has also shown we can use inkjet printing to place cells in specific locations on a surface and may prove an alternate method to register cells with microelectrodes.
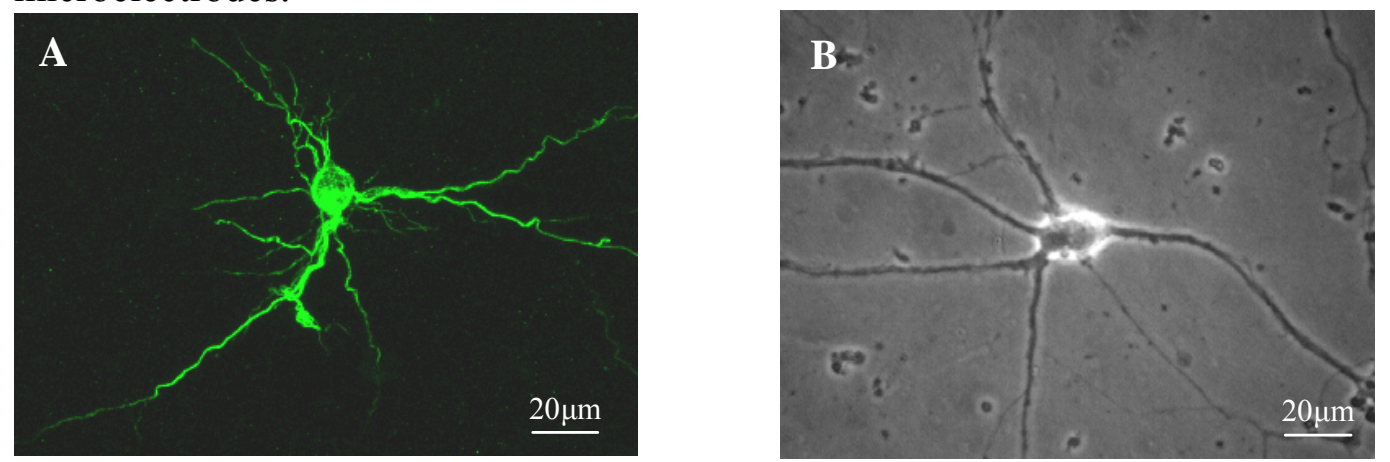

Figure 6. Embryonic hippocampal cells in 3D (left panel, immunostained for neurofilaments) and 2D cultures (right panel, phase contrast). 

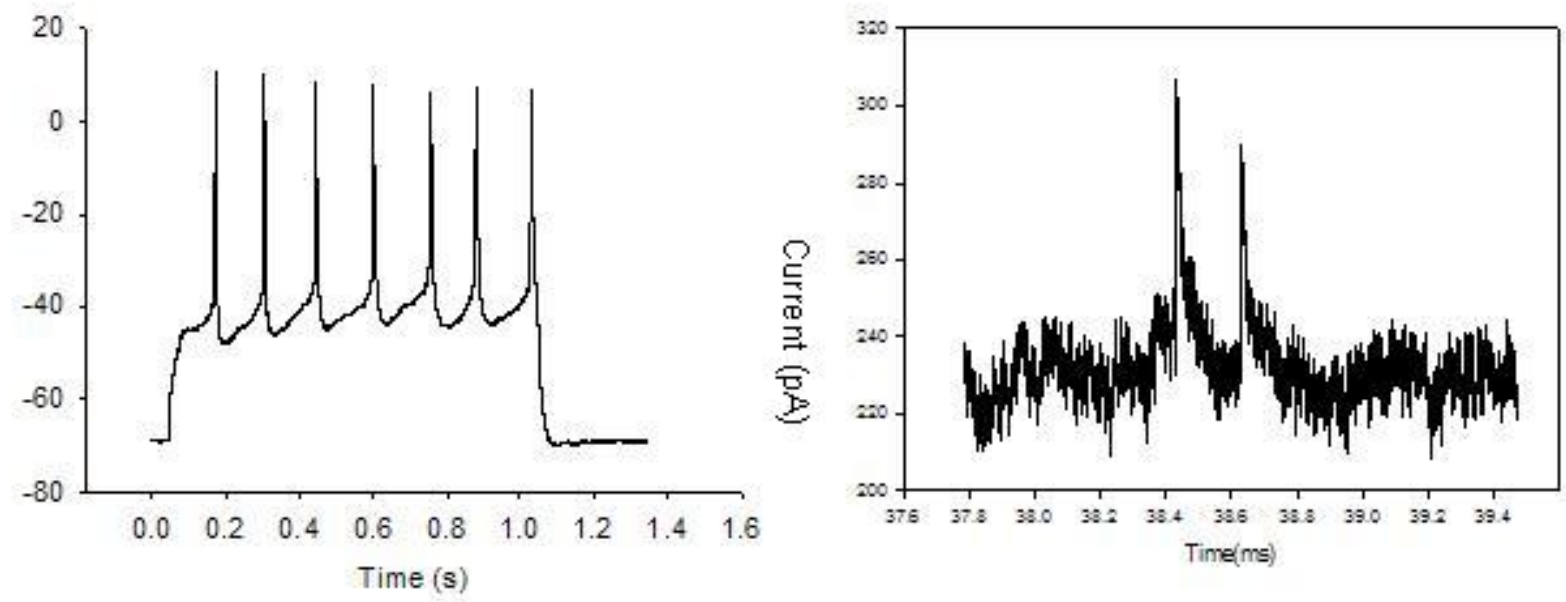

Figure 7. The electrophysiological parameters of the hippocampal neurons were not different in 3D cultures compared to the control 2D cultures. Left panel: repetitive firing of a hippocampal pyramidal cell cultured in a 3D collagen hydrogel recorded with whole-cell patch clamp methods. Right panel: spontaneous Inhibitory PostSynaptic Currents recorded from hippocampal neurons cultured in our 3D culture system after 12 days in vitro.

\begin{tabular}{|c|c|c|c|c|c|c|c|c|c|c|c|c|}
\hline \multirow{2}{*}{\begin{tabular}{|l} 
Passive \\
Property
\end{tabular}} & \multicolumn{4}{|l|}{ Day 4} & \multicolumn{4}{|l|}{ |Day 7} & \multicolumn{4}{|c|}{ Day 14} \\
\hline & 3D & & 2D & & 3D & & 2D & & 3D & & 2D & \\
\hline VM (mV) & -25.76 & \pm 4.01 & -35.72 & \pm 4.47 & -23.54 & \pm 5.16 & -31.81 & \pm 4.22 & -22.61 & \pm 3.61 & -35.78 & \pm 5.76 \\
\hline RN (M ) & 867 & \pm 215 & 1028 & \pm 238 & 537 & \pm 181 & 647 & \pm 207 & 159 & \pm 60 & 220 & \pm 92 \\
\hline CM (pF) & 18.74 & \pm 6.98 & 14.95 & \pm 7.63 & 18.47 & \pm 7.85 & 16.61 & \pm 5.05 & 30.5 & \pm 13.46 & 32.44 & \pm 16.67 \\
\hline L to/t1 & 3.03 & \pm 1.37 & 1.56 & \pm 0.60 & 1.67 & \pm 0.52 & 2.33 & \pm 0.61 & 2.33 & \pm 0.61 & 1.86 & \pm 0.45 \\
\hline Tau0(ms) & 44.09 & \pm 18.07 & 53.80 & \pm 23.14 & 50.74 & \pm 26.3 & 39.51 & \pm 15.12 & 14.93 & \pm 5.35 & 11.11 & \pm 5.26 \\
\hline $\begin{array}{l}\text { TVCi1 (ms) } \\
\text { Na current }\end{array}$ & 0.49 & \pm 0.13 & 0.48 & \pm 0.16 & 0.8 & \pm 0.38 & 0.67 & \pm 0.22 & 1.53 & \pm 0.44 & 1.01 & \pm 0.4 \\
\hline $\begin{array}{l}(\mathrm{pA}) \\
\mathrm{K} \text { current }\end{array}$ & -934 & \pm 466 & -973 & \pm 1066 & -2562 & \pm 842 & -2282 & \pm 651 & -2297 & \pm 818 & -3455 & \pm 897 \\
\hline$(p A)$ & 1508 & \pm 639 & 1166 & \pm 462 & 2806 & \pm 620 & 2189 & \pm 1004 & 2178 & \pm 1243 & 2439 & \pm 709 \\
\hline Vthr(mv) & -35.99 & \pm 4.8 & -35.18 & \pm 2.79 & -42.85 & \pm 7.08 & -44.87 & \pm 4.30 & -44.11 & \pm 6.15 & -47.69 & \pm 4.6 \\
\hline Ithr(pA) & 65.71 & \pm 12.72 & 99.44 & \pm 42.90 & 55 & \pm 13.84 & 54.44 & \pm 18.10 & $142.7 \varepsilon$ & \pm \pm 50.26 & 108.00 & \pm 22.8 \\
\hline $\begin{array}{l}\text { Firing type } \\
\text { Max firing }\end{array}$ & 1.33 & \pm 1 & 1.00 & \pm 0.00 & 2 & \pm 1 & 2.11 & \pm 1.17 & 2.55 & \pm 1.51 & 1.86 & \pm 1.46 \\
\hline $\begin{array}{l}(\mathrm{Hz}) \\
\text { AP Ampl. }\end{array}$ & 1.33 & \pm 1 & 1.00 & \pm 0.00 & $\mid 2.5$ & \pm 1.38 & 3.11 & \pm 3.02 & 5.09 & \pm 4.7 & 3.71 & \pm 5.62 \\
\hline$(\mathrm{mV})$ & 0.86 & \pm 3.79 & -1.02 & \pm 14.92 & 18.2 & \pm 4.38 & 15.05 & \pm 6.79 & 14.25 & \pm 7.44 & 13.09 & \pm 12.86 \\
\hline AP Dur(ms) & 7.57 & \pm 1.49 & 12.35 & \pm 8.30 & 5.47 & \pm 2.3 & 5.17 & \pm 1.55 & 4.22 & \pm 1.52 & 5.08 & \pm 1.95 \\
\hline $\begin{array}{l}\text { (mV) } \\
\text { AHP Dur. }\end{array}$ & -2.82 & \pm 0.87 & -3.55 & \pm 2.28 & $\mid-3.53$ & \pm 0.95 & -5.37 & \pm 1.84 & -4.17 & \pm 0.93 & -4.08 & \pm 0.97 \\
\hline$(\mathrm{ms})$ & 86.78 & \pm 14.64 & 57.22 & \pm 22.89 & 129.48 & \pm 38.72 & 77.54 & \pm 22.80 & 92.78 & \pm 24.72 & 59.39 & \pm 19.51 \\
\hline$n$ & 9 & & 12 & & 8 & & 12 & & 11 & & & 9 \\
\hline
\end{tabular}

Table 1. Comparison of passive properties of hippocampal neurons culture in the 3D and 2D models.

We have also investigated the use of alternative surface to create patterns. Patterns were created for an antibody to the NGF receptor for hippocampal neurons as the positive surface and 
tenacsin- $\mathrm{C}$ as the negative surface. Figure 8 indicates the methodology used and patterns achieved utilizing this method.
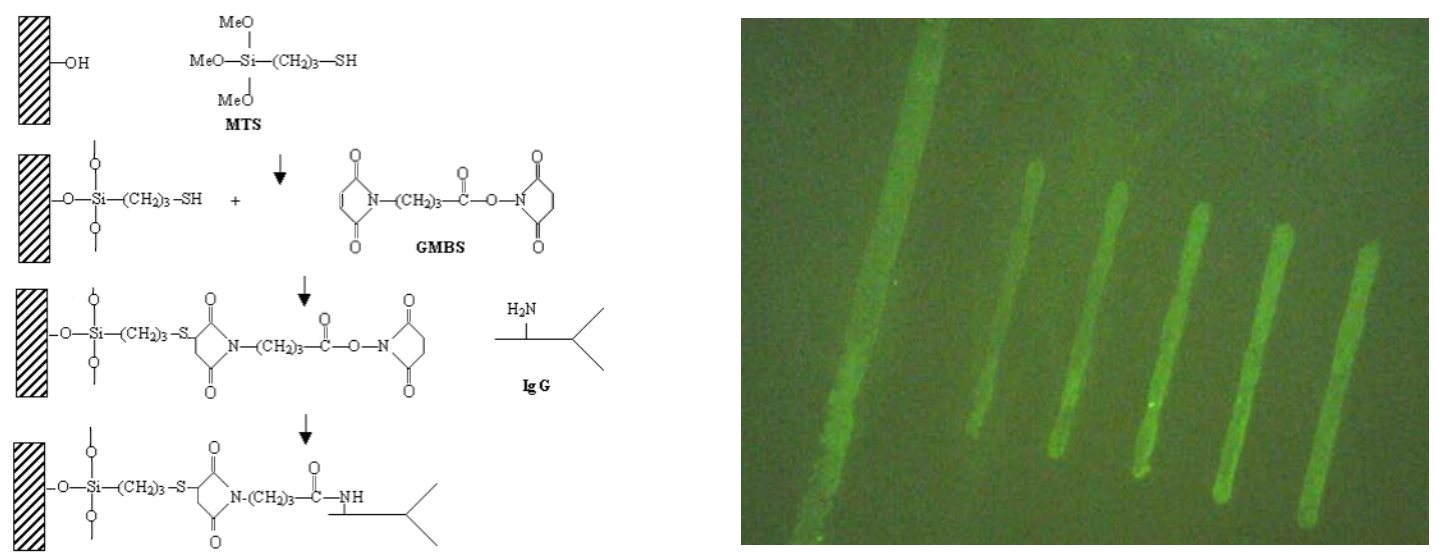

Figure 8. Protein patterns created by the stamping method with GMBS crosslinker and visualized by immunostaining.

Task 3 successfully tested the dynamics of the system as shown in Figure 9 utilizing dual patchclamp electrophysiology. These experiments established the two cell circuits as models for the study of a compound's effects on LTP circuits. However, aligning the two cell circuits with the MEAs proved problematic and directional studies of the signal propagation in arrays of neurons on the MEAs was undertaken as a proof-of-concept of the system first.
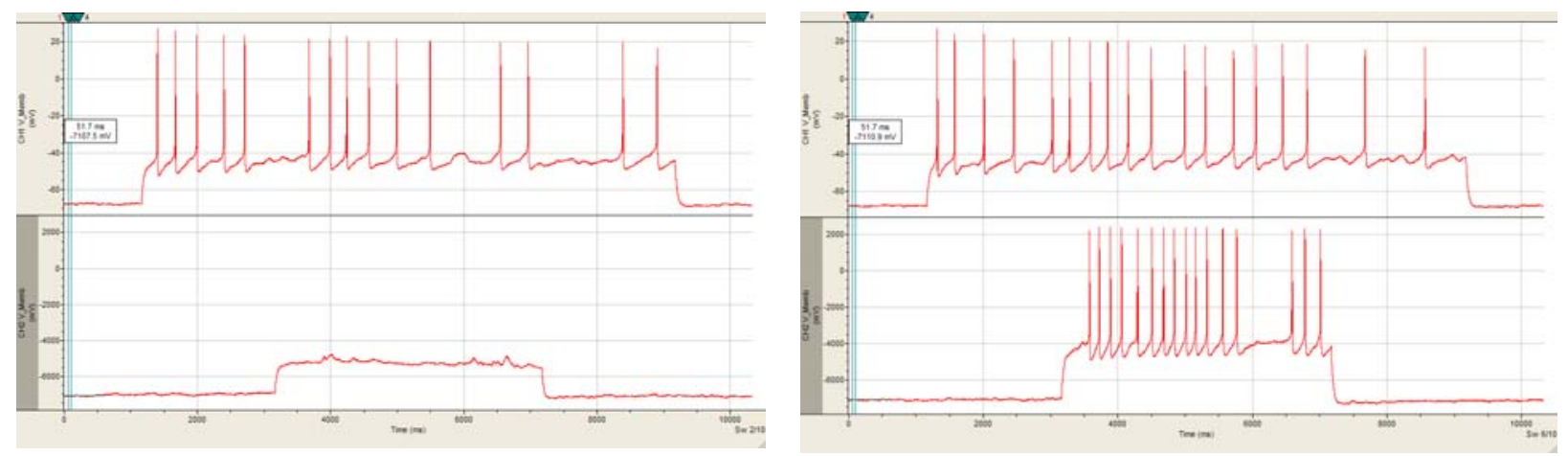

Figure 9. Experimental protocol to study network dynamics in engineered networks. The interaction of two weakly coupled (established according to the protocol above) hippocampal pyramidal cells was measured using dual patchclamp recording method. Action potentials were evoked in both cells with current injection in current clamp mode. Statistical methods to analyze firing patterns in the presence and absence of incoming action potentials from the other cells are under development.

\section{Network Activity Measured in Microelectrode Arrays}

The networks generated spontaneous action potentials and this initial activity was recorded with the substrate-embedded electrodes (Figure 10) using the directional patterned neurons. 

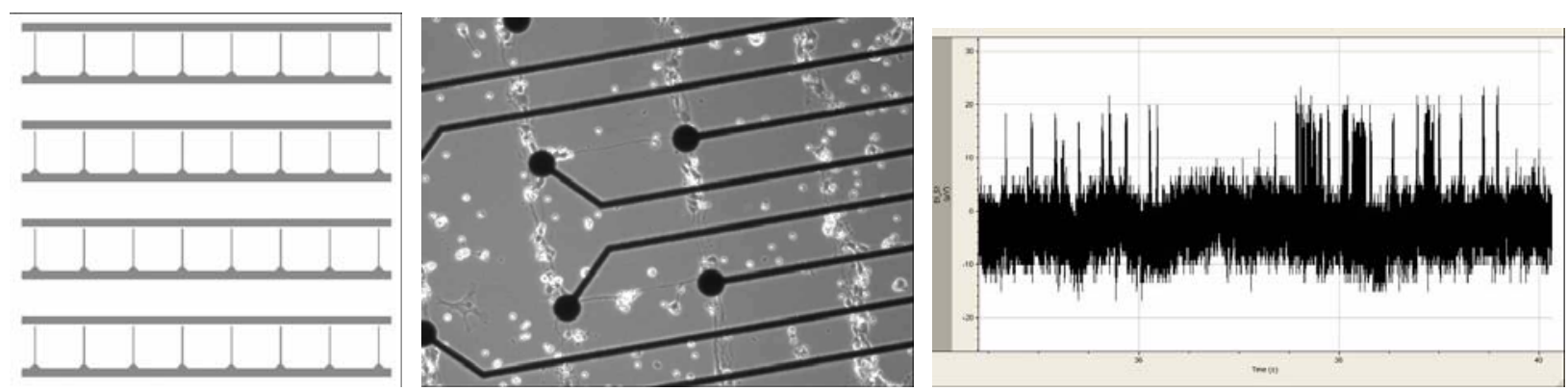

Figure 10. Two-cell layer pattern on substrate-embedded electrodes. The interconnectivity pattern on the mask (left) between the two layers was asymmetrical, thus enhancing the probability of one-directional connections. Embryonic hippocampal cells complied to the patterns (middle) showed normal spontaneous firing properties (right).

We have finalized our pattern design for the multiple-cell networks on multielectrode arrays as shown in Figure 10 and can stimulate and record from the patterns. The formation of directional connections between the two cell layers is clearly visible (Figure 11). The long-term stability of the patterned networks has been achieved for periods of up to a month. Future work should establish this duration for at least 2-3 months.
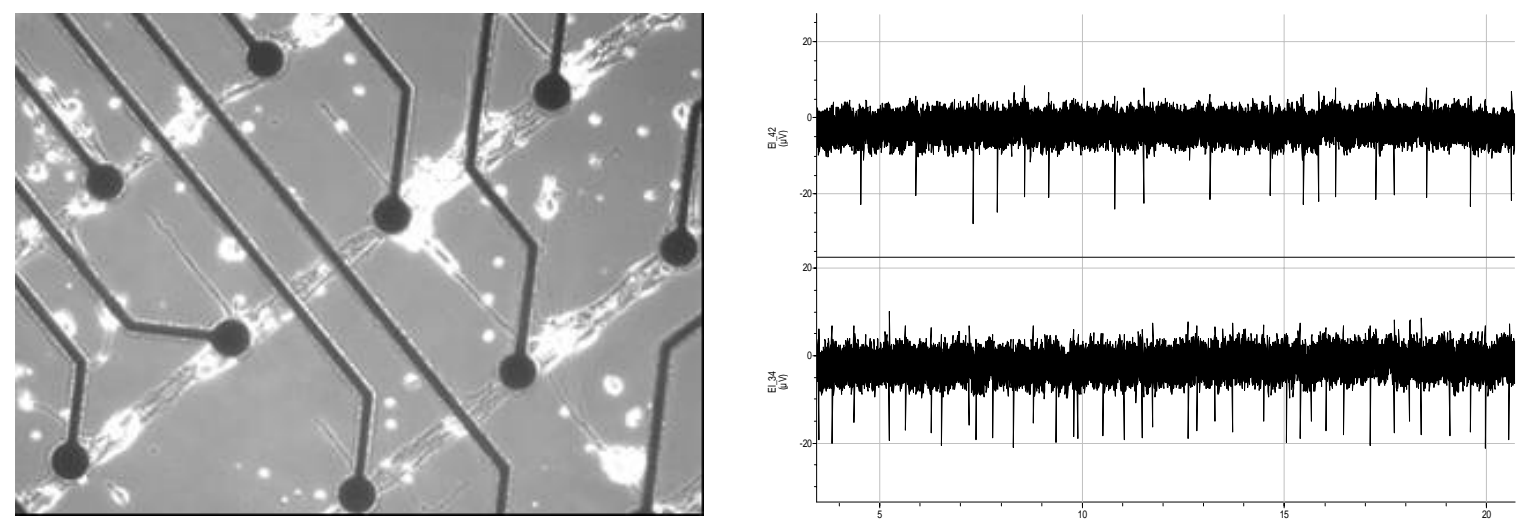

Figure 11. Formation and electrical activity of multiple-cell networks on multielectrode arrays.

The significance of the creation of the functional neuronal networks for toxin screening is self evident, but this system will also be useful for drug screening applications as a high-throughput method to study synaptic transmission. It is the first system to enable the study of LTP and LTD in a high-throughput way and can also be used to create functional models for neurodegenerative diseases.

We have also developed the mathematical tools necessary to analyze directional connectivity in engineered neuronal networks (Figure 12). We have created MATLAB programs for import recorded data into MATLAB and an interactive graphical interface to create raster plots and cross-peri-spike histograms to evaluate directional connectivity. 

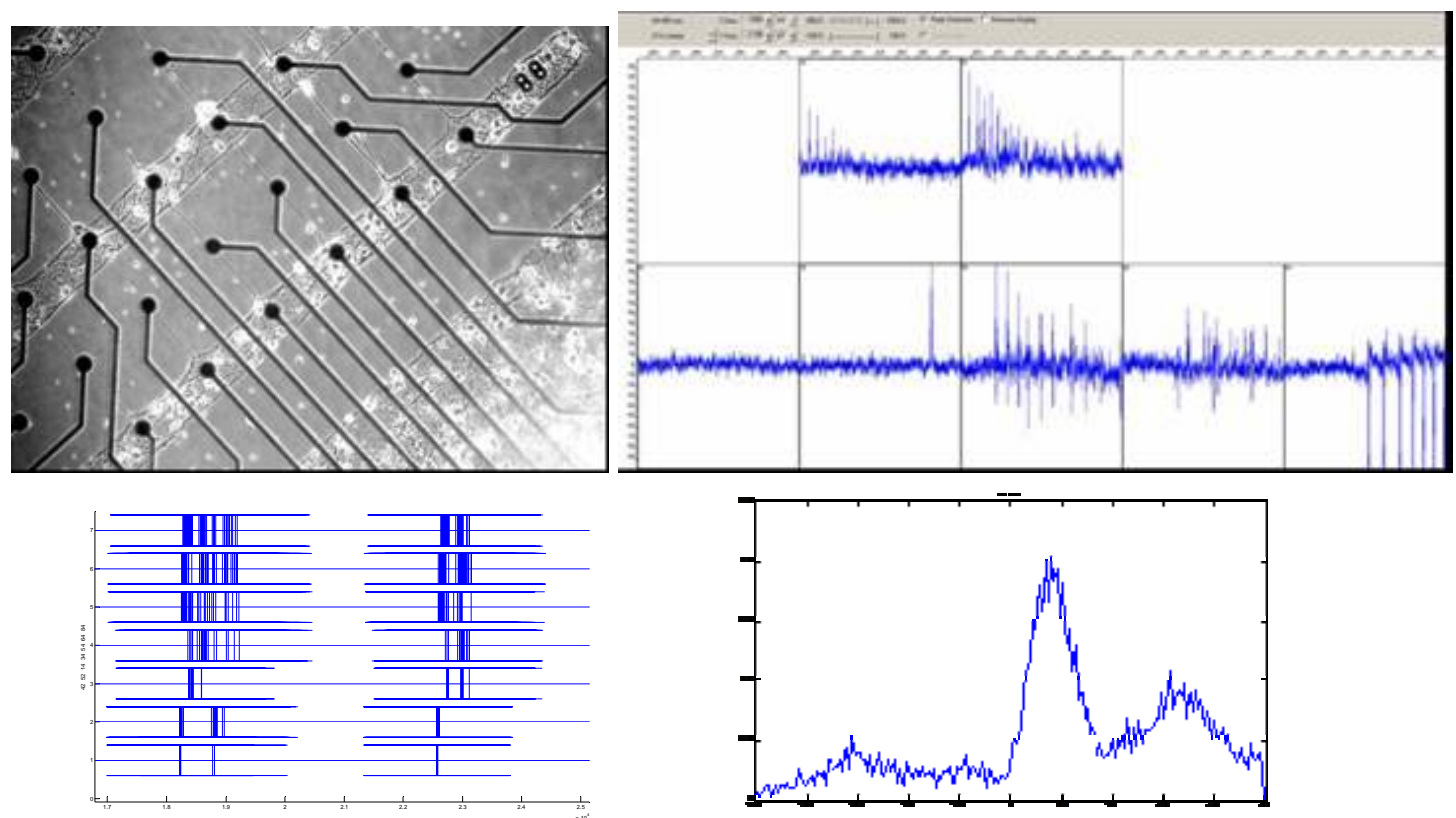

Figure 12. Demonstration of directional connectivity in engineered neuronal networks. Upper left panel: Phase contrast picture of an engineered hippocampal network on microelectrode arrays with guided connectivity. Upper panel: Extracellularly recorded spontaneous action potentials form the cell layers. Lower left: Raster plot of action potential firing show synchronized burst firing between channels. Lower right: The Peri-spike time histogram between channels 42 and 64 is strongly asymmetric, indicating asymmetric connectivity between the two cell layers. (Firing on electrodes $\mathrm{x} 2$ preceded firing on electrodes $\mathrm{x} 4$ ).

We have continued the work to improve the pattern longevity and fidelity of the defined culture system on the array. We performed extensive testing of different methods to enhance the longevity and stability of the neuronal networks. We have developed a novel method to use collagen hydrogels to stabilize the cellular patterns and enhance sensitivity of electorphysiological recordings (Figure 13). These are very important problems which must be solved before long-term field application of the functional biosensor.
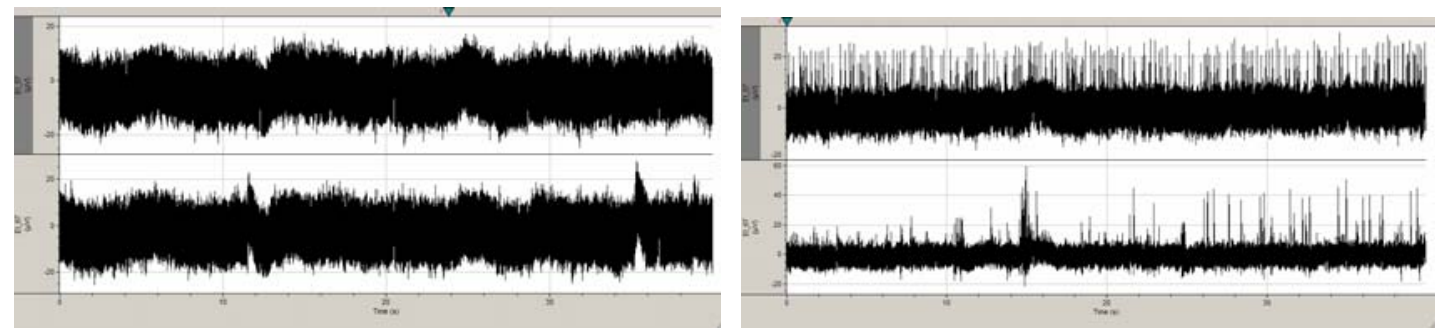

Figure 13. Effect of collagen encapsulation on multielectrode recording from hippocampal cells. In preliminary experiments collagen hydrogel encapsulation improved the Signal/Noise ratio in exteracellular multielectrode recordings. Left: before collagen. Right: after collagen.

\section{Adult Neuronal Cultures}

One of the criticisms of utilizing embryonic neurons as models for in vivo systems is that they may not be representative of the adult tissue. With this in mind, we set out to culture adult hippocampal neurons in our defined culture systems and to determine if they are amenable to all of the techniques we have developed for the embryonic hippocampal neurons. Figure 14 shows that we were highly successful in this endeavor and the culture system is now routine in the 
Hybrid Systems Laboratory. We believe this is the only laboratory in the world in which this is the case.
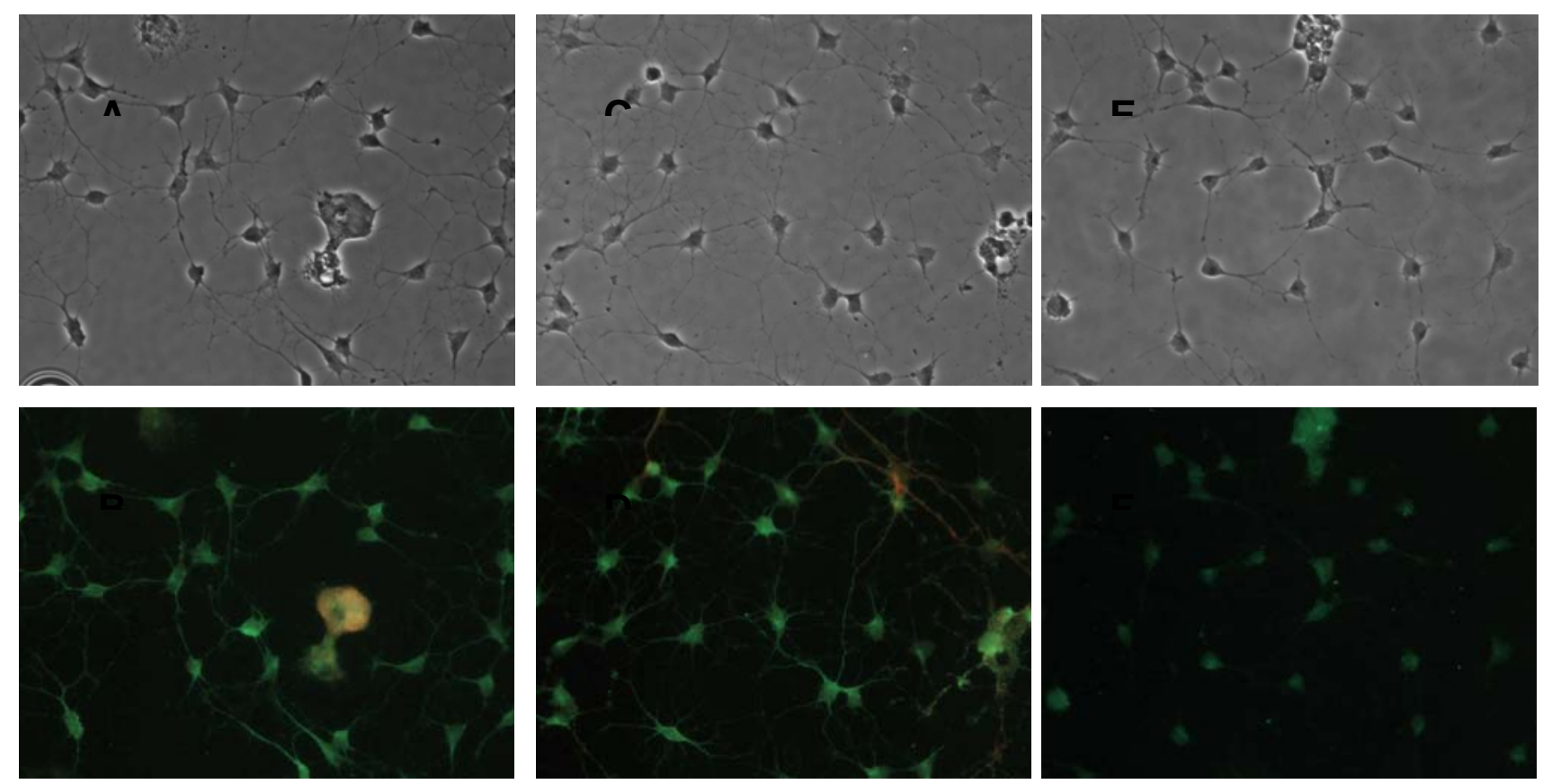

Figure 14. Purified rat hippocampal neurons plated on DETA coverslips. (A, C) Day 35 cultures, phase contrast, Scalebar: $\mathrm{xx \mu m}$. (B, D) Day 35 cultures, anti-neurofilament (green) and anti-glial (red), epifluorescent picture, Scalebar xx $\mu \mathrm{m}$. (E, F) Day xx cultures, Anti-glutamic acid decarboxylase (red) and anti-glutamate transporter (green), epifluorescent pictures.

\section{Addition of glutamate to serum free culture improves the electrical properties of adult hippocampal neurons in vitro}

The electrophysiological and morphological characteristics of adult hippocampal neurons grown on artificial Silane surfaces has also been studied. The characteristic properties of these cells have been compared with in vivo hippocampal neurons, with large differences noted between the two. In this study we attempted to optimize the hippocampal culture through the addition of the neurotransmitter glutamate in order to capture more normal electrophysiological properties in cultured neurons. Cells for study were morphologically selected, pyramidal neurons with large branching apical dendrites, small basal dendrite, and single axon. Glutamate was added to the serum-free medium after 14 days in culture at a concentration of $25 \mu \mathrm{M}$. After additional days in culture, the number of cells displaying voltage-sensitive inward currents followed by sustained voltage-sensitive outward currents increased significantly. In addition, the percentage of cells displaying characteristic action potentials increased substantially. These results indicate that glutamate improves in vitro regeneration of normal neuronal electrical properties. 

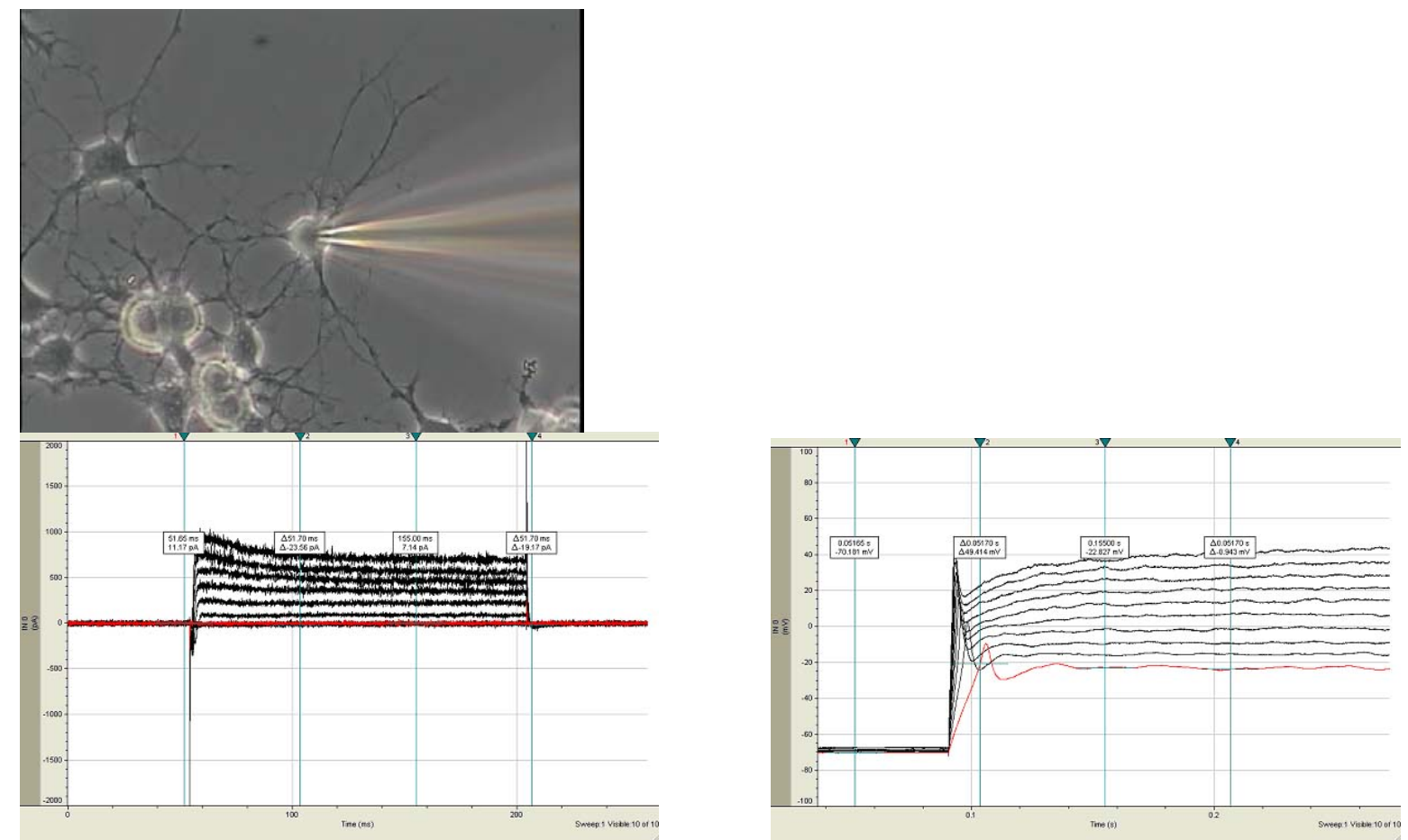

Figure 15. Top panel: Hippocampal neurons two months post plating, positive electrical characteristics. Bottom 2 panels: Electrophysiological characterization of adult rat hippocampal neurons grown on DETA coverslips. (bottom, left panel) Representative recording of sodium and potassium currents obtained from a day 35 neuron grown, glutamate added on Day 14. Bottom, right panel: Representative recording of an action potential firing, Day 35 neuron plus glutamate.

\section{Patterning of Adult Hippocampal Neurons}

One of the most important discoveries on the grant was that the adult hippocampal neurons also could be patterned (Figure 16). This now enables all of the technology developed for the embryonic cells to be applied to the adult neurons.
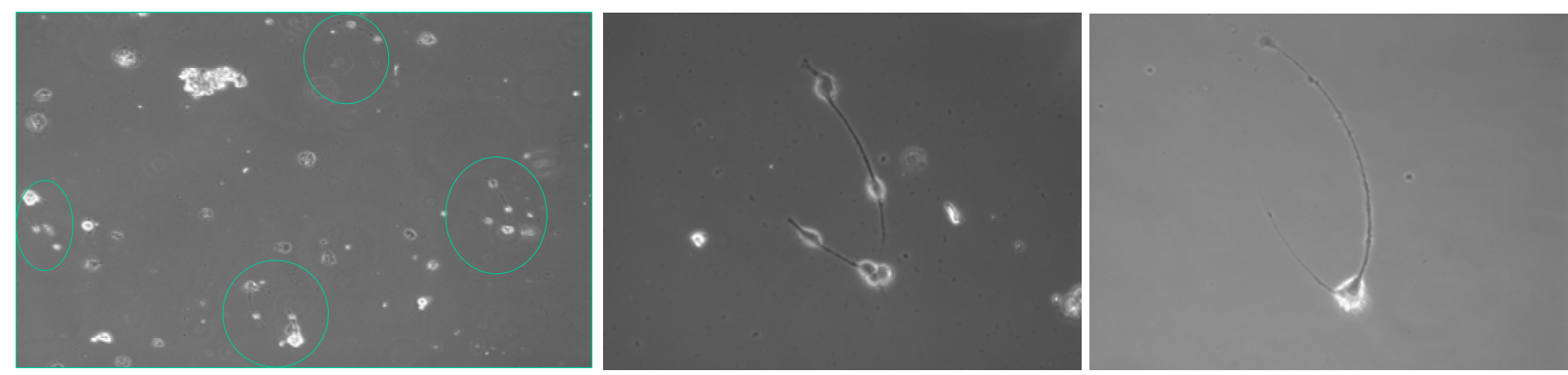

Figure 16. Patterned neurons on oval pattern (Fish Pattern). Left Panel: 10x view with multiple patterns forming (pattern formation not complete, neurites outgrowth ongoing). Middle and Right Panel: Good cell body and neurite attachment to adhesive surface of patterns (Phase-contrast at 20x magnification).

\section{Cardiac Hybrid System Toxin Detection Results}

Finally, in the previous two granting periods we had conducted some toxicity experiments using cardiac cells on microelectrode arrays. We have continued those experiments as a COST SHARE and the highlights of those results are included in this report.

Multielectrode extracellular recording of spontaneous action potentials of chicken cardiac myocytes was validated as an environmental toxin detection method. For the validation 
of our system we used drugs which have a known effect on cardiac myocyte physiology such as epinephrine, verapamil and isoproteronol. After standardization we used our system to show that common environmental toxins such as cadmium and pesticides could be detected in acute and also in chronic experiments at physiological concentrations (Figure 17).
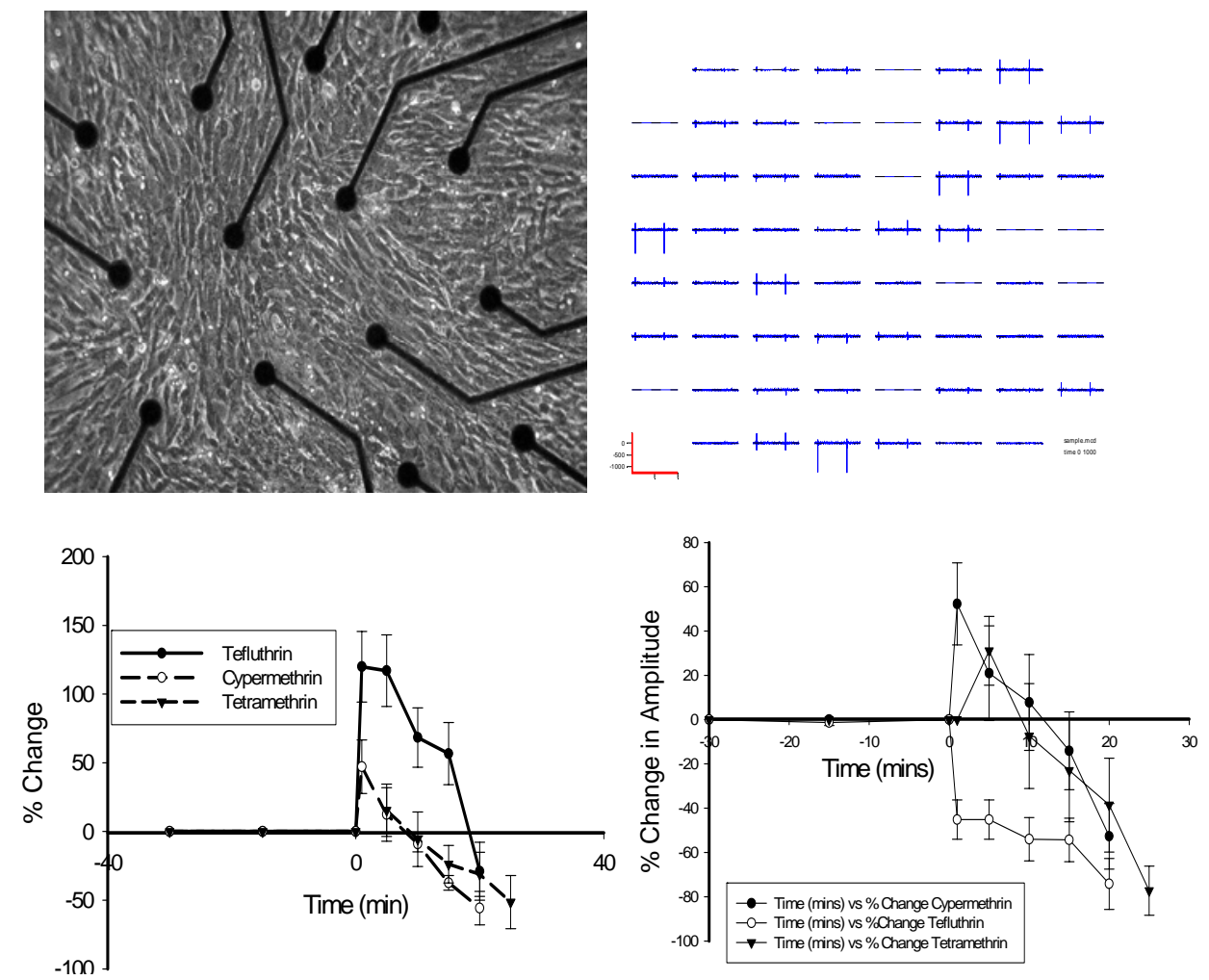

Figure 17. By day 3 cardiac myocytes formed a spontaneously beating monolayer over the recording electrodes (upper left). On day 5 multielectrode extracellular recordings were performed (upper right). Pesticides were applied in the extracellular solution. The toxins were affecting the frequency (bottom left) and the amplitude (bottom right) of the extracellularly recorded action potentials at physiological concentrations.

In order to validate our toxin detection system and to compare FET-based systems with metal electrode-based systems we recorded two widely used ionotrop agent with our MEA system and compared the results to earlier FET experiments as shown in Figure 18. 

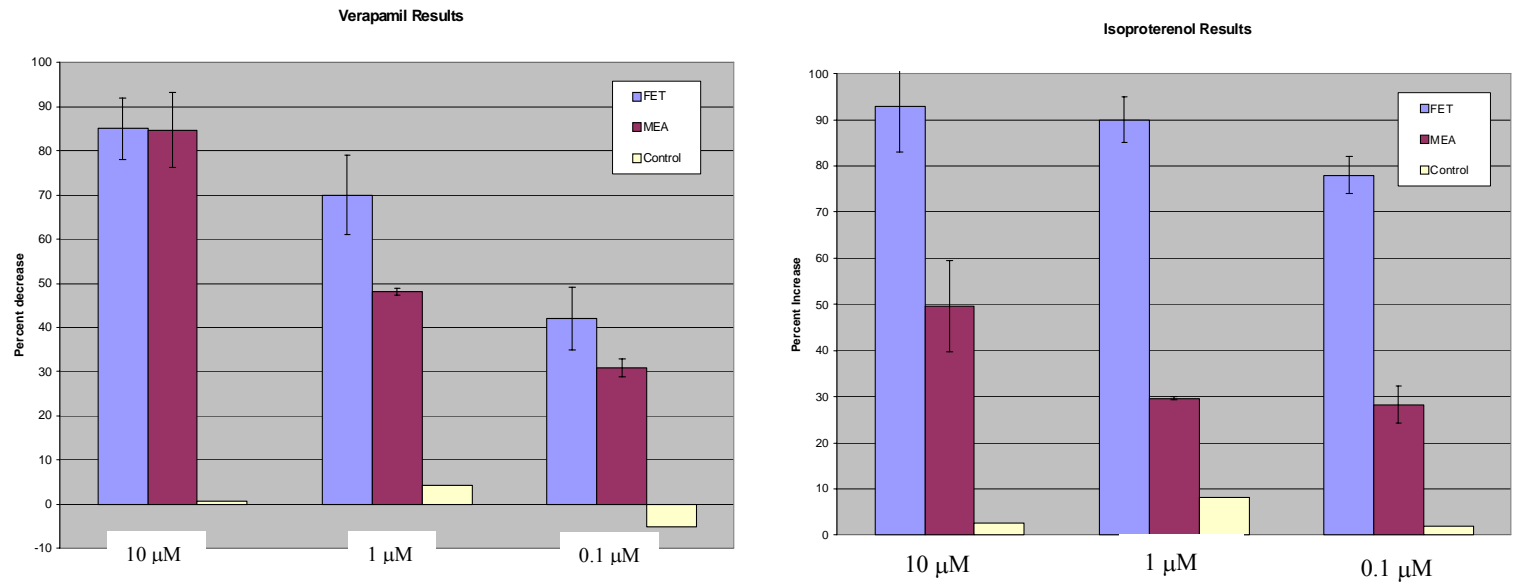

Figure 18. Effect of verapamil and isoproterenol on the spontaneous action potential generation of cultured chicken cardiac myocytes measured by metal MEAs and Field Effect Transistors.

We have also extended our methods to pattern physiologically active cardiac myocytes and skeletal muscle myotubes to build novel biosensors or hybrid neuronal/muscle systems. We have performed calcium imaging on cardiac myocytes patterns and demonstrated that there is no spread of excitation between distinct parts of the patterns (Figure 19).
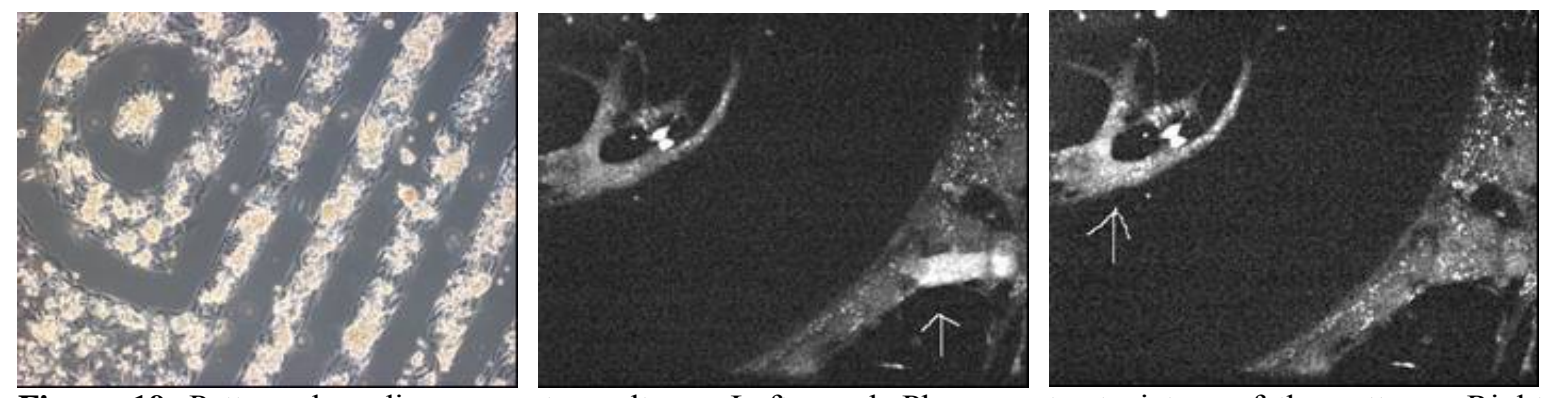

Figure 19. Patterned cardiac myocytes cultures. Left panel: Phase contrast picture of the patterns. Right panel: Calcium imaging showed independent propagating activity (arrows) in the distinct parts of patterned cardiac myocytes cultures indicating that 1) the cardiac myocytes are physiologically healthy and 2) the patterning is effective and successful.

\section{Conclusion:}

This has been a highly successful research program in that, over the time course of the funding for this research, we can now routinely create well-defined patterns of hippocampal neurons in vitro. It is important that we can recreate these well-defined culture circuits from hippocampal neurons as the hippocampus is the portion of the brain that most think is responsible for learning and memory and many other cognitive functions. It is also one of the more susceptible regions of the body for toxins and disease, as damage to these neurons and their circuits have profound impact on animal or human function. We have also been able to model these simple circuits as well as align them with microelectrode arrays (MEA) that together enable the rudimentary sensor systems that were envisioned when the initial grant was funded. Advances in the basic biology of the embryonic hippocampal neurons have enabled us to create mixed populations of excitatory and inhibitory phenotypes on the patterns. This crucial result is one of the most fundamental processes we would like to mimic in vitro, that is important in vivo, is long-term potentiation (LTP) and long-term depression (LTD). LTP has now successfully been 
demonstrated utilizing patterns of hippocampal neurons on MEAs. This result, along with the techniques that make fabrication of these devices routine, were the primary goals of this project and they have now been achieved. Thus, the capability that was originally anticipated form this work, which are sensor systems, utilizing living neurons that could act as sensors for toxins or other environmental effects and how this affects cognitive functions has been achieved. In addition, detection of these affects can be made without cell death.

While we have achieved the main objective of this research, these are not the only significant results that have been achieved. We have also demonstrated for the first time that these culture systems could also be created from adult hippocampal neurons and that these systems could survive for at least 2-3 months and they are minimal to the same patterning methodologies as the embryonic cells. The importance of utilizing adult cells is that, even though our group and many others has shown that embryonic hippocampal cells can be made to exhibit many of the same functions as found in mature hippocampal cells, there is always the question as to whether or not they exhibit the full range of properties one would find in an adult cell in vivo. By now being able to routinely culture the adult cells, you can use these directly either in the sensor systems themselves or in control systems to verify that the mature embryonic cultures possess the same properties as the fully developed adult cells because the adult cells can be manipulated using the same surface chemistry techniques as the embryonic cells. It should be minimal to integration with MEA systems.

Finally, as a conclusion to some work that was initiated in an earlier granting period where we used cardiac cells as we did not have the facilities to do primary neuronal culture at that time, we have also established robust cell-based systems based on cardiac MEA constructs. These systems have been shown to be excellent toxin sensors and show great promise for a wide variety of applications in sensors.

\section{BIBLIOGRAPHY}

V. Thakore, A. Behal, P. Molnar, D.C. Leistritz, and J.J. Hickman, "Nanoscale Nonlinear Dynamic Characterization of the Neuron-Electrode Junction" (accepted for publication in $J$. Comput. Theor. Nanosci.)

A. Natarajan, C.J. Chun, J.J. Hickman and P. Molnar, "Growth and Electrophysiological Properties of Rat Embryonic Cardiomyocytes on Hydroxyl- and Carboxyl-Modified Surfaces," (accepted for publication in Journal of Biomaterials Science: Polymer Edition).

M. Ramalingam, P. Molnar, K. P. Rao and J. J. Hickman, "Biomaterial Surface patterning utilizing self assembled monolayers to control neuronal cell behavior", Journal of Biomedical Engineering and Technology, Review (In Press 2008)

A. Natarajan, P. Molnar, K. Sieverdes, K. Jamshidi and J.J. Hickman, "Multielectrode Recordings of Cardiac Action Potentials as a High Throughput Method to Evaluate Pesticide Toxicity," Toxicology In Vitro 20(3):375-381 (2006).

D. K Mohan, P. Molnar and J.J. Hickman. "Toxin detection based on action potential shape analysis using a realistic mathematical model of differentiated NG108-15 cells" Biosensors \& Bioelectronics 21:1804-1811 (2006). 
T. Xu, J. Jin, C. Gregory, J.J. Hickman and T. Boland, "Inkjet Printing of Viable Mammalian Cells,” Biomaterials 26(1):93-99 (2005).

M. Das, P Molnar, C. Gregory, L. Riedel and J. J. Hickman, "Long-term Culture Of Embyonic Rat Cardiomyocytes on an Organosilane Surface in a Serum Free Medium," Biomaterials 25(25):5643-5647 (2004).

T. Xu, S. Petridou, E. Lee, E. Roth, N. Vyavahare, J. J. Hickman, and T. Boland, "Construction of High-Density Bacterial Colony Arrays and Patterns by the Ink-jet Method," Journal of Biotechnology \& Bioengineering, 85:29 (2004).

E. A. Roth, T. Xu, M. Das, C. Gregory, J. J. Hickman and T. Boland, "Inkjet Printing for High Throughput Cell Patterning," Biomaterials 25(17): 3707-3715 (2004).

LIST OF ACRONYMS AND ABBREVIATIONS

LTP Long-term Potentiation

LTD Long-term Depression

DETA N-1[3-(trimethoxysilyl) propyl] diethylenetriamine

FET Field Effect Transistors

MEA Microelectrode Array

\section{REFEREED CONFERENCE PROCEEDINGS}

K. Varghese, P. Molnar, N. Bhargava, M. Das, M.S. Kindy and J.J. Hickman, "High Throughput Pharmacological Screening using Cell-Based Biosensors" American Vacuum Society annual meeting, Oct. 14-19, 2007, Seattle, WA.

A. Natarajan, N. Bhargava, P. Molnar, M. Das, and J. J. Hickman, "Surface modification and photolithographic patterning of microelectrode arrays for cell-based biosensor applications" American Vacuum Society annual meeting, Oct. 14-19, 2007, Seattle, WA.

A. Natarajan, P. Molnar, N. Bhargava, V. Dhir, M. Das, K. Varghese and J.J. Hickman, "Surface modification and photolithographic patterning of microelectrode arrays for cell-based biosensor applications" 234th ACS National Meeting, August 19-23, 2007. Boston, MA, USA

P. Molnar,_D.K.Mohan and J.J.Hickman, "Toxin detection based on action potential shape analysis using a realistic mathematical model of NG108 - 15 cells 687 Computational and Simulation Techniques I" Society for Neuroscience 2005, Nov. 11-16, 2005, Washington, DC.

J.F. Kang, M. Poeta, L. Riedel, M. Das, C. Gregory, P. Molnar and J.J. Hickman, "MicroFabrication of Patterned Neural Network" Florida TechTransfer Conference, Orlando, FL (2005).

A. Natarajan, K. Varghese, D. Leistritz, P. Molnar and J.J. Hickman, "Cell Based Biosensors for Drug Discovery and Toxin Detection” Florida TechTransfer Conference, Orlando, FL (2005). 
P. Molnar, J-F. Kang, N. Bhargava, M. Das, A. Natarajan and J.J. Hickman, "Characterization and applications of engineered neuronal networks" Society for Neuroscience 2006, Oct. 13-18, 2006, Atlanta, GA.

P. Molnar, M. Kuchma, A. Natarajan, J.F. Kang, N. Bhargava, M. Das and J.J. Hickman, "Photolithographical patterning of single cells and cell assemblies on commercial multielectrode arrays", Proceeding of the $5^{\text {th }}$ International Meeting on Substrate-Integrated Micro Electrode Arrays, Reutlingen, Germany (2006).

J.K. Kang, P. Molnar, M. Das, L. Riedel, C.J. Chun, K. Wilson and J.J. Hickman, "Patterned Neuronal Networks for High-Throughput Functional Drug Screening and for Functional Models of Neurodegenerative Diseases" Society for Neuroscience, Washington, DC (2005).

K. Varghese, A. Natarajan, A. Jamshidi, P. Molnar, J.J. Hickman, "High Throughput Toxin Evaluation", 4th International meeting, Substrate Integrated Micro-Electrode Arrays, July 2004, Reutlingen, Germany

D. Leistritz, P. Molnar, A. Natarajan, K. Varghese and J.J. Hickman. "Development of a CellBased Biosensor for Compound Detection," $24^{\text {th }}$ Army Science Conference (2004).

J. Kang, L. Riedel, M. Das, C. Gregory, P. Molnar, W. Wang and J.J. Hickman, "Engineered Neuronal Networks for Robotics, Neurocomputing, Toxin Detection and Rehabilitation" Biotechnology Institute, National Tsing Hua University, Taiwan (2004).

P. Molnar, M. Das, C. Gregory, L. Riedel, J. Kang, C. Chun, K. Wilson, and J.J. Hickman, "Engineered Neuronal Networks for High-Throughput Functional Drug Screening and for Functional Models of Neurodegenerative Diseases," BioFlorida Symposium (2004).

D. Mohan, P. Molnar, and J.J. Hickman. "Action Potential Shape Analysis for Detecting Toxins in Warfare, using a Realistic Mathematical Model of Differentiated NG108-15 Cells," $24^{\text {th }}$ Army Science Conference (2004).

C. Chun, S. Narayanan, M. Poeta, W. Wang, and J.J. Hickman. "Neuronal Cell Patterning on Covalently Bound Protein Patterns by Micro-Contact Printing Techniques and the Functioning of Proteins Bound on Silane Monolayers," $24^{\text {th }}$ Army Science Conference (2004).

J. Kang, M. Das, C. Gregory, P. Molnar, L. Riedel, W. Wang and J.J. Hickman. "Patterned Neuronal Networks for Robotics, Neurocomputing, Toxin Detection and Rehabilitation," $24^{\text {th }}$ Army Science Conference (2004).

K. Varghese, A. Natarajan, A. Jamshidi, P. Molnar, M. Das, C. Gregory, and J.J. Hickman, "Characterization of Cardiac Myocytes on Different Surface Modifications and Their Subsequent Use in a High Throughput Toxin Detection System," Proc. Soc. Biomat., (2003).

W. Wang, J.J. Hickman, and T. Boland, "Study of Surface Modification Methods for Cell Adhesion and Patterning," Proc. Soc. Biomat., (2003). 
H.E. Canavan, M.E. Teliska, P.M. Natishan, J.J. Hickman, W.E. O'Grady, D.E. Ramaker, "Surface-Induced Disruption of Disulfide Bonds in Extracellular Matrix Proteins," Proc. Soc. Biomat., (2003).

K. Lenghaus, J. Dale, D. Henry, S. Sundaram, J. Jenkins, M. Tarlov, L. Locascio, J. Evju, and J.J. Hickman, "Towards Understanding the Effects of Surface Modification on the Biointerface in Biosensors," ACS Symposium Series, Polymer Edition (2003).

J.J. Hickman, J.K. Peterson, and M.S. Ravenscroft, "Nanoscale Surface Manipulation to Build Hybrid Devices for Sensor Applications," DOE Proceedings of the $20^{\text {th }}$ Symposium on Energy Engineering Sciences, (2002).

\section{PUBLISHED ABSTRACTS}

T. Xu, P. Molnar, C. Gregory, M. Das, T. Boland, J. Hickman, "Electrophysiology of Embryonic Hippocampal Cells Grown in 3D Artificial Environments," $5^{\text {th }}$ Annual Frontiers in Neuroscience Research Day, MUSC, February 13, 2004.

P. Molnar, M. Das, C. Gregory, L. Riedel, M. Poeta, J. Hickman, "Engineered Neuronal Networks to Model Physiology and Pathophysiology of the Central Nervous System," $5^{\text {th }}$ Annual Frontiers in Neuroscience Research Day, MUSC, February 13, 2004.

D. Leistritz, P. Molnar, A. Jamshidi, J. Hickman "Validation of a High Throughput System to Test Antiarrhythmic Drugs," $5^{\text {th }}$ Annual Frontiers in Neuroscience Research Day, MUSC, February 13, 2004.

A. Natatajan, P. Molnar, K. Sievedes, A. Jamshidi, J. Hickman, "Drug Testing and Environmental Toxin Detection using Cell-based Biosensors," AVS 50 ${ }^{\text {th }}$ International Symposium \& Exhibition, November 4, 2003.

K. Varghese, A. Jamshidi, K. Sievedes, P. Molnar, M. Das, C. Gregory, J. Hickman, "Cellbased Biosensors- A Tool for High Throughput Toxin Detection," AVS $50^{\text {th }}$ International Symposium \& Exhibition, November 4, 2003.

T. Xu, P. Molnar, C. Gregory, M. Das, J. Hickman, T. Boland, "In-Vitro Electrophysiological Comparison of Embryonic Hippocampal Neurons Grown in 2D and 3D Environments," AVS $50^{\text {th }}$ International Symposium \& Exhibition, November 4, 2003.

D. Mohan, P. Molnar, W. Wang, T. Boland, J. Hickman, K. Poole, "Optimization of the CellElectrode Interface for High-Throughput Toxin Detection. A Combined Computer Modeling and Electrophysiological Study Using NG108-15 Cells Cultured on Surface-Modified Microelectrodes," BioInterface 2003 conference, October 22-24, 2003.

J. Hickman, "Building Hybrid Neuroelectric Devices," Neuroscience Symposium, October 9, 2003. 
M. Das, C. Gregory, L. Riedel, P. Molnar, C. Chun, A. Jamshidi, J. Hickman, " Creation of Tissues Engineered Constructs by Long-term Culture of Cardiomyocytes on Organosilane," Biomedical Engineering Society, October 3, 2003, Nashville, TN.

K. Varghese, A. Natatajan, A. Jamshidi, M. Das, P. Molnar, C. Gregory, J. Hickman, "Characteristics of Cardiac Myocytes on Different Surface Modifications and Their Subsequent Use in a High Throughput Toxin Detection System," Society for Biomaterials, May 2, 2003.

W. Wang, J. Hickman, T. Boland, "Study of Surface Modification Methods for Cell Adhesion and Patterning," Society for Biomaterials, May 2, 2003.

J. Hickman, K. Lenghaus, J. Dale, D. Henry, S. Sundaram, J. Jenkins, L. Locascio, M. Tarlov, J. Evju, "Toward Understanding the Effects of Surface Modification on the Biointerface in Biosensors," American Chemical Society, March 24, 2003.

K. Varghese, D. Leistritz, A. Jamshidi, P. Molnar, J. Hickman, "High Throughput Toxin Detection System using Cell-Based Biosensors," Clemson University Research Forum, March 9, 2003, Clemson, SC.

T. Xu, M. Das, J. Hickman, T. Boland, "Patterned Construction of Three-Dimensional Neuronal Networks Using Ink Jet Directed Layer-by-Layer Deposition," AVS $49^{\text {th }}$ International Symposium \& Exhibition, November 4-8, 2002.

W. Wang, M. Poeta, J. Hickman, T. Boland, "Multi-Electrode Arrays Surface Modification by Aligned Microcontact Printing," AVS $49^{\text {th }}$ International Symposium \& Exhibition, November 4$8,2002$.

M. Yacopucci, S. Narayanan, A. Jamshidi, A. Natatajan, K. Varghese, J. Hickman, "Engineering the Close Contact of Electrically Active Cells with Array Microelectrodes," AVS $49^{\text {th }}$ International Symposium \& Exhibition, November 4-8, 2002.

J. Hickman, M. Das, P. Molnar, "Integration of Cells and Silicon Devices via Surface Microengineering," AVS 49 ${ }^{\text {th }}$ International Symposium \& Exhibition, November 4-8, 2002.

J. Hickman, "Integration of Cells and Proteins with Silicon Devices via Surface Microengineering," BioDevice Interface Science and Technology Workshop, September 9, 2002.

J. Hickman, J. Peterson, M. Ravenscroft, "Nanoscale Surface Manipulation to Build Hybrid Devices for Sensor Applications," $20^{\text {th }}$ Symposium on Energy Engineering Sciences, May 21, 2002.

\section{PRESENTATIONS}

J.J. Hickman, "Mechanistic Evaluation of Airborne Particulates using Neuronal Based Assays." August 9, 2006, $9^{\text {th }}$ Annual Force Health Protection Conference, Albuquerque, NM. Invited 
J.J. Hickman, "The Creation of Functional Cellular Circuits and Their Integration with Siliconbased Devices for Biosensor Application." August 10, 2006, $9^{\text {th }}$ Annual Force Health Protection Conference, Albuquerque, NM. Invited

J.J. Hickman, "Integration of Cells and Proteins with Silicon Devices via Surface Microengineering." November 11, 2005, Science Seminar Series, Daytona Beach community College, Daytona Beach, FL. Invited

J.J. Hickman, "Integration of Cells and Proteins with Silicon Devices via Surface Microengineering" Zyvex Corporation, July 18, 2005, Richardson, TX. Invited

J.J. Hickman, "Hybrid in Vitro Systems for Toxin Detection, Functional Drug Screening and as Disease Models." Florida TechTransfer Conference, May 18-19, 2005, Orlando, FL Invited

J.J. Hickman, "The Creation of Cellular Circuits and Their Integration with Silicon-based Devices for Biological Applications." FL ASM, March 31- April 2, 2005, Ft. Lauderdale, FL. Invited

J.J. Hickman, "Analysis of Protein Adsorption under Flow and Static Conditions in Microfluidic Devices.” FL AVS, March 14-16, 2005, Orlando, FL. Invited

J.J. Hickman, "The Creation of Neuronal Circuits and Their Integration with Silicon-based Devices for Biological Computation Applications." IASTED, CSS 2004, November 28 December 1, 2004, Clearwater Beach, FL. Keynote Speaker. Invited

J.J. Hickman, "Building Hybrid Neuroelectric Systems." Western North Carolina Society for Neuroscience Symposium, May 4, 2004, Wake Forest University, Winston-Salem, NC. Invited

J.J. Hickman, "Integration of Cells and Proteins with Silicon Devices via Surface MicroEngineering." National Institute for Biomedical Imaging and Bioengineering, April 23, 2004, Rockville, MD. Invited

J.J. Hickman, "Direct Monitoring of Signal Pathways by Extracellular Electrophysiology of Neurons." DARPA/DSO workshop, April 22, 2004, Arlington, VA. Invited

J.J. Hickman, "Engineering Cardiac Myocyte Hybrid Systems - Applications for Biocompatibility, Toxin Detection and High-throughput Screening." $8^{\text {th }}$ Annual Hilton Head Workshop, Cardiovascular Tissue Engineering, March 6-10, 2004, Hilton Head, SC.

T. Xu, P. Molnar, C. Gregory, M. Das, T. Boland, J.J. Hickman, "Electrophysiology of Embryonic Hippocampal Cells Grown in 3D Artificial Environments," $5^{\text {th }}$ Annual Frontiers in Neuroscience Research Day, MUSC, March 19, 2004.

P. Molnar, M. Das, C. Gregory, L. Riedel, M. Poeta, J.J. Hickman, "Engineered Neuronal Networks to Model Physiology and Pathophysiology of the Central Nervous System," $5^{\text {th }}$ Annual Frontiers in Neuroscience Research Day, MUSC, March 19, 2004. 
D. Leistritz, P. Molnar, A. Jamshidi, J.J. Hickman "Validation of a High Throughput System to Test Antiarrhythmic Drugs," $5^{\text {th }}$ Annual Frontiers in Neuroscience Research Day, MUSC, March 19, 2004.

J.J. Hickman, "Integration of cells and Silicon Devices via Surface Microengineering to Build Hybrid Neuroelectric Devices." Mechanical Engineering Seminar Series at LSU, February 12, 2004, Baton Rouge, LA. Invited

J.J. Hickman, K. Lenghaus, D. Henry, P. Molnar, K. Wilson, M. Das, S. Sundaram and J. Jenkins, "Building Hybrid Cellular Systems." HSARPA Bioinformatics and Advance Assay Workshop, February 3, 2004, Washington DC. Invited

A. Natatajan, P. Molnar, K. Sievedes, A. Jamshidi, J.J. Hickman, "Drug Testing and Environmental Toxin Detection using Cell-based Biosensors," AVS $50^{\text {th }}$ International Symposium \& Exhibition, November 4, 2003.

K. Varghese, A. Jamshidi, K. Sievedes, P. Molnar, M. Das, C. Gregory, J.J. Hickman, "Cellbased Biosensors- A Tool for High Throughput Toxin Detection," AVS 50 ${ }^{\text {th }}$ International Symposium \& Exhibition, November 4, 2003.

T. Xu, P. Molnar, C. Gregory, M. Das, J.J. Hickman, T. Boland, "In-Vitro Electrophysiological Comparison of Embryonic Hippocampal Neurons Grown in 2D and 3D Environments," AVS $50^{\text {th }}$ International Symposium \& Exhibition, November 4, 2003.

D. Mohan, P. Molnar, W. Wang, T. Boland, J.J. Hickman, K. Poole, "Optimization of the CellElectrode Interface for High-Throughput Toxin Detection. A Combined Computer Modeling and Electrophysiological Study Using NG108-15 Cells Cultured on Surface-Modified Microelectrodes," BioInterface 2003 conference, October 22-24, 2003.

J.J. Hickman, "Building Hybrid Neuroelectric Devices." University of Southern California Provost's Neuroscience Symposium, October 9, 2003, Los Angeles, CA. Invited

M. Das, C. Gregory, L. Riedel, P. Molnar, C. Chun, A. Jamshidi, J.J. Hickman, “ Creation of Tissues Engineered Constructs by Long-term Culture of Cardiomyocytes on Organosilane," Biomedical Engineering Society, October 3, 2003, Nashville, TN.

J.J. Hickman, "Development of Hybrid Cellular Systems via Surface Microengineering." Georgia Institute of Technology, September 25, 2003, Atlanta, GA. Invited

J.J. Hickman, "Building Minimalistic Hybrid Neuroelectric Devices." University of Southern California, September 8, 2003, Los Angeles, CA. Invited

J.J. Hickman, "Integration of Neuronal Systems with Silicon Microstructures for New Hybrid Diagnostic Devices." Neuroscience Grand Rounds, Medical University of South Carolina, August 14, 2003, Charleston, SC. Invited 
J.J. Hickman, Integration of Cells and Silicon Devices via Surface Microengineering." North Carolina State University / University of North Carolina Joint Seminar Series. June 4-6, 2003, Raleigh, NC. Invited

K. Varghese, A. Natatajan, A. Jamshidi, M. Das, P. Molnar, C. Gregory, J.J. Hickman, "Characteristics of Cardiac Myocytes on Different Surface Modifications and Their Subsequent Use in a High Throughput Toxin Detection System," Society for Biomaterials, May 2, 2003.

W. Wang, J.J. Hickman, T. Boland, "Study of Surface Modification Methods for Cell Adhesion and Patterning," Society for Biomaterials, May 2, 2003.

K. Lenghaus, J. Dale, D. Henry, J. Jenkins, J.J. Hickman, "Design and Experimental Validation of a MEMS Device Testbed to Create Biocompatible Systems," Society for Biomaterials, May 2, 2003.

J.J. Hickman, K. Lenghaus, J. Dale, D. Henry, S. Sundaram, J. Jenkins, L. Locascio, M. Tarlov, J. Evju, "Toward Understanding the Effects of Surface Modification on the Biointerface in Biosensors," American Chemical Society, March 24, 2003.

K. Varghese, D. Leistritz, A. Jamshidi, P. Molnar, J.J. Hickman, "High Throughput Toxin Detection System using Cell-Based Biosensors," Clemson University Research Forum, March 9, 2003, Clemson, SC.

J.J. Hickman, "Integration of Cells and Silicon Devices via Surface Microengineering to Create Minimalistic Cellular Systems." Winter Conference of Neural Plasticity, February 27, 2003, Guadeloupe, French Antilles. Invited

J.J. Hickman, "Integration of Cells and Silicon Devices via Surface Microengineering." Bioengineering Dept., University of Florida, November 26, 2002, Gainesville, FL. Invited

J.J. Hickman, M. Das, P. Molnar, "Integration of Cells and Silicon Devices via Surface Microengineering." AVS $49^{\text {th }}$ International Symposium, November 3-8, 2002, Denver, CO.

T. Xu, M. Das, J.J. Hickman, T. Boland, "Patterned Construction of Three-Dimensional Neuronal Networks Using Ink Jet Directed Layer-by-Layer Deposition,” AVS $49^{\text {th }}$ International Symposium \& Exhibition, November 3-8, 2002.

W. Wang, M. Poeta, J.J. Hickman, T. Boland, "Multi-Electrode Arrays Surface Modification by Aligned Microcontact Printing," AVS $49^{\text {th }}$ International Symposium \& Exhibition, November 3$8,2002$.

M. Yacopucci, S. Narayanan, A. Jamshidi, A. Natatajan, K. Varghese, J.J. Hickman, "Engineering the Close Contact of Electrically Active Cells with Array Microelectrodes," AVS $49^{\text {th }}$ International Symposium \& Exhibition, November 3-8, 2002.

J.J. Hickman, "Integration of Cells and Silicon Devices via Surface Microengineering." 
University of South Carolina, October 21, 2002, Columbia, SC. Invited

J.J. Hickman, "Integration of Cells and Proteins with Silicon Devices via Surface Microengineering." BioDevice Interface Science and Technology Workshop, September 9, 2002, Scottsdale, AZ. Invited

J.J. Hickman, J. Peterson, M. Ravenscroft, "Nanoscale Surface Manipulation to Build Hybrid Devices for Sensor Applications." 20th Symposium on Energy Engineering Sciences, Argonne National Laboratory, May 21, 2002, Chicago, IL. Invited

\section{JOURNAL ARTICLES}

V. Thakore, A. Behal, P. Molnar, D.C. Leistritz, and J.J. Hickman, "Nanoscale Nonlinear Dynamic Characterization of the Neuron-Electrode Junction" (accepted for publication in $J$. Comput. Theor. Nanosci.)

A. Natarajan, C.J. Chun, J.J. Hickman and P. Molnar, "Growth and Electrophysiological Properties of Rat Embryonic Cardiomyocytes on Hydroxyl- and Carboxyl-Modified Surfaces," (accepted for publication in Journal of Biomaterials Science: Polymer Edition).

M. Ramalingam, P. Molnar, K. P. Rao and J. J. Hickman, "Biomaterial Surface patterning utilizing self assembled monolayers to control neuronal cell behavior", Journal of Biomedical Engineering and Technology, Review (In Press 2008)

A. Natarajan, P. Molnar, K. Sieverdes, K. Jamshidi and J.J. Hickman, "Multielectrode Recordings of Cardiac Action Potentials as a High Throughput Method to Evaluate Pesticide Toxicity," Toxicology In Vitro 20(3):375-381 (2006).

D. K Mohan, P. Molnar and J.J. Hickman. "Toxin detection based on action potential shape analysis using a realistic mathematical model of differentiated NG108-15 cells" Biosensors \& Bioelectronics 21:1804-1811 (2006).

T. Xu, J. Jin, C. Gregory, J.J. Hickman and T. Boland, "Inkjet Printing of Viable Mammalian Cells," Biomaterials 26(1):93-99 (2005).

M. Das, P Molnar, C. Gregory, L. Riedel and J. J. Hickman, "Long-term Culture Of Embyonic Rat Cardiomyocytes on an Organosilane Surface in a Serum Free Medium," Biomaterials 25(25):5643-5647 (2004).

T. Xu, S. Petridou, E. Lee, E. Roth, N. Vyavahare, J. J. Hickman, and T. Boland, "Construction of High-Density Bacterial Colony Arrays and Patterns by the Ink-jet Method," Journal of Biotechnology \& Bioengineering, 85:29 (2004).

E. A. Roth, T. Xu, M. Das, C. Gregory, J. J. Hickman and T. Boland, "Inkjet Printing for High Throughput Cell Patterning," Biomaterials 25(17): 3707-3715 (2004). 


\section{PAPERS IN PREPARATION FOR SUBMISSION}

J.F. Kang, M.G. Poeta, L.M. Riedel, D.C. Henry, M. Das, C. Gregory, J.J. Hickman, “Coplanar Patterns of Self-Assembled Monolayers: Incorporation of Perfluoroalkyltrichlorosilane into Triaminealkylmethoxysilane monolayer and its Impact on Patterning Motoneurons"..

N. Bhargava, M. Das, D. Edwards, M. Stancescu, J.-F. Kang and J.J. Hickman, “Coexpression of glutamate vesicular transporter (VGLUT1) and choline acetyltransferase (ChAT) proteins in fetal rat hippocampal neurons in culture".

T. Xu, P, Molnar, C. Gregory, M. Das, T. Boland and J.J. Hickman, "Electrophysiological characterization of embryonic hippocampal neurons cultured in 3D collagen hydrogel".

A. Natarajan, P. Molnar, M. Stancescu, and J.J. Hickman, "Engineered Neuronal Networks with directed functionality for Drug Development and the Study of LTP and LDP”.

A. Natarajan, P. Molnar, M. Stancescu, and J.J. Hickman, "Patterned Cardiac Myocytes in a Novel Serum Free Medium for High-Throughput drug Screening Applications".

\section{BOOK CHAPTERS}

P. Molnar and J. J. Hickman, "Modeling of Action Potential Generation inNG108-15 Cells" in Patch Clamp Methods and Protocols Humana Press Methods in Molecular Biology Series, (July 2007).

P. Molnar, J. F. Kang, N. Bhargava, M. Das and J. J. Hickman, "Synaptic Connectivity in Engineered Neuronal Networks" in Patch Clamp Methods and Protocols Humana Press Methods in Molecular Biology Series, (July 2007).

J.J. Hickman, "Building Minimalistic Hybrid Neuroelectric Devices," in Toward Replacement Parts for the Brain: Implantable Biomimetic Electronics as Neural Prosthetic (T.W. Berger and D.L. Glanzman Eds.), $1^{\text {st }}$ edition. Cambridge, MA: MIT Press (2005). 